Article

\title{
Comparing the Potential of Multispectral and Hyperspectral Data for Monitoring Oil Spill Impact
}

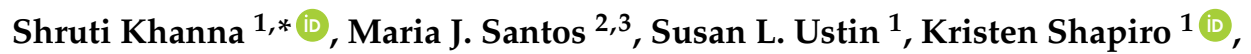 \\ Paul J. Haverkamp ${ }^{1,4}$ and Mui Lay ${ }^{1}$ \\ 1 Center for Spatial Technologies and Remote Sensing, Department of Land Air and Water Resources, \\ University of California, One Shields Avenue, Davis, CA 95616, USA; slustin@ucdavis.edu (S.L.U.); \\ kdshapiro@ucdavis.edu (K.S.); pjhav@ucdavis.edu (P.J.H.); mclay@ucdavis.edu (M.L.) \\ 2 Department of Innovation, Environmental and Energy Sciences, Utrecht University, \\ 3584 CS Utrecht, The Netherlands; maria.dossantos@geo.uzh.ch \\ 3 Department of Geography, University of Zürich, 8057 Zürich, Switzerland \\ 4 Department of Evolutionary Biology and Environmental Studies, University of Zürich, \\ 8057 Zürich, Switzerland \\ * Correspondence: shrkhanna@ucdavis.edu
}

Received: 24 January 2018; Accepted: 8 February 2018; Published: 12 February 2018

\begin{abstract}
Oil spills from offshore drilling and coastal refineries often cause significant degradation of coastal environments. Early oil detection may prevent losses and speed up recovery if monitoring of the initial oil extent, oil impact, and recovery are in place. Satellite imagery data can provide a cost-effective alternative to expensive airborne imagery or labor intensive field campaigns for monitoring effects of oil spills on wetlands. However, these satellite data may be restricted in their ability to detect and map ecosystem recovery post-spill given their spectral measurement properties and temporal frequency. In this study, we assessed whether spatial and spectral resolution, and other sensor characteristics influence the ability to detect and map vegetation stress and mortality due to oil. We compared how well three satellite multispectral sensors: WorldView2, RapidEye and Landsat EMT+, match the ability of the airborne hyperspectral AVIRIS sensor to map oil-induced vegetation stress, recovery, and mortality after the DeepWater Horizon oil spill in the Gulf of Mexico in 2010. We found that finer spatial resolution $(3.5 \mathrm{~m})$ provided better delineation of the oil-impacted wetlands and better detection of vegetation stress along oiled shorelines in saltmarsh wetland ecosystems. As spatial resolution become coarser $(3.5 \mathrm{~m}$ to $30 \mathrm{~m})$ the ability to accurately detect and map stressed vegetation decreased. Spectral resolution did improve the detection and mapping of oil-impacted wetlands but less strongly than spatial resolution, suggesting that broad-band data may be sufficient to detect and map oil-impacted wetlands. AVIRIS narrow-band data performs better detecting vegetation stress, followed by WorldView2, RapidEye and then Landsat $15 \mathrm{~m}$ (pan sharpened) data. Higher quality sensor optics and higher signal-to-noise ratio (SNR) may also improve detection and mapping of oil-impacted wetlands; we found that resampled coarser resolution AVIRIS data with higher SNR performed better than either of the three satellite sensors. The ability to acquire imagery during certain times (midday, low tide, etc.) or a certain date (cloud-free, etc.) is also important in these tidal wetlands; WorldView2 imagery captured at high-tide detected a narrower band of shoreline affected by oil likely because some of the impacted wetland was below the tideline. These results suggest that while multispectral data may be sufficient for detecting the extent of oil-impacted wetlands, high spectral and spatial resolution, high-quality sensor characteristics, and the ability to control time of image acquisition may improve assessment and monitoring of vegetation stress and recovery post oil spills.
\end{abstract}

Keywords: vegetation indices; LANDSAT; WorldView-2; RapidEye; AVIRIS 


\section{Introduction}

Coastal wetlands are important but vulnerable ecosystems that provide valuable ecosystem services such as protection from storms and storm surges, support for fisheries and seafood industries, nursery sites for juvenile fish, carbon storage, nutrient cycling, waterfowl habitat and other key services [1-8]. Coastal wetlands are also subject to relatively frequent disturbances such as hurricanes and other storms, changes in sea level, and contamination from runoff, tidal inputs, and oil spills, all of which cause vegetation stress and wetland degradation [9-13]. This can cause lasting damage for years to decades [13-16]. Since 1973, both the volume and number of oil spill incidents has declined in the United States [17]. However, large oil spill events still cause disproportionate impacts in the wetlands where they occur. The DeepWater Horizon (DWH) oil spill in the Gulf of Mexico in 2010 was the biggest oil spill in the US history and the second-largest in the world [18]. The DWH spill occurred in deep oceanic pipelines, which were difficult to contain. In total, 206 million gallons of oil were released over 85 days from 20 April to 19 July, which contaminated 572 miles of gulf shoreline [18]. The effects of the DWH oil spill on the Gulf of Mexico wetlands are likely still ongoing, as demonstrated by several recent studies [16,19-24].

Oil is highly detrimental to plant health, both directly and indirectly. Oil affects plant metabolism directly as coating the leaves prevents gas exchange between the leaves and the atmosphere, significantly increasing leaf and plant mortality [25-29]. Oil also affects plants indirectly when present in the soil by reducing oxygen exchange between the atmosphere and soil, affecting the microbial community and nutrient cycling $[15,25,26,30]$. At the ecosystem level, post-oil spill senescent and dead plant material slowly erodes resulting in a transition from wetland to bare soil or water [25]. The recovery from oil effects can take months to several years $[13,15,31]$, especially since different wetland communities differ in their susceptibility to oil impacts $[14,32,33]$.

As plants become increasingly stressed, they lose pigments, water, and ultimately leaves, all of which can be measured through changes in their reflectance [34-38]. Plant stress affects plant reflectance in regions of the electromagnetic spectrum related to plant pigment concentration [35-37,39,40], water content [41-43], and leaf area or canopy density [44]. Most multispectral satellite sensors have at least four fundamental bands: Blue, Green, Red, and Near InfraRed (NIR) [45]. Vegetation indices based on these bands are effective in tracking both pigment and leaf area [46,47]. The Shortwave InfraRed (SWIR) band is available on some freely available multispectral sensors like Landsat or the European Space Agency's Sentinel-2 satellites and is used to measure plant water content [43]. Vegetation indices calculated from imaging spectrometers can track all of these changes as demonstrated by Khanna et al. [20] after the DWH oil spill. Change in land cover due to loss of wetland vegetation can be tracked through "angle indices", which are relatively insensitive to the confounding influence of soil moisture [44,48]. Thus, imaging spectrometer data is useful in mapping and monitoring oil spill impacts on wetland extent and oil induced vegetation stress [49-52].

Few studies have assessed the post-oil spill stress on wetland vegetation, and then, most have used imaging spectrometer data [20,49,53-55]. The objective of this study is to explore the potential for using easily available multispectral sensor data to detect and map vegetation stress and mortality due to oil contamination. We sought to determine whether oil-induced plant stress can be detected and monitored using multispectral satellite imagery with fine (WorldView-2 and RapidEye; $2 \mathrm{~m}$ and $5 \mathrm{~m}$ ) and moderate spatial resolutions (Landsat ETM+; pan sharpened $15 \mathrm{~m}$ or $30 \mathrm{~m}$ ). We contrast multispectral sensors with airborne AVIRIS imagery in their abilities to detect vegetation stress in oiled versus oil-free shores. Each sensor has different characteristics regarding spectral, spatial, and radiometric resolution, and sensor engineering, all of which might influence the potential of the sensor data to monitor oil spill impacts.

\section{Data and Methods}

\subsection{Study Area}

Barataria Bay is located approximately $160 \mathrm{~km}$ from the DWH oil spill site in an interlobe basin between the current Bird's Foot delta and the abandoned Lafourche delta lobes [56]. The dominant 
plant species in the low intertidal saltmarshes is Spartina alterniflora (saltmarsh cordgrass) and Juncus roemerianus (needlegrass rush), with subdominants Spartina patens (salt meadow cordgrass), Distichlis spicata (saltgrass) and Batis maritima (saltwort) more common in the higher marsh [57]. As the DWH oil spill occurred offshore, the oil came in with the tide and primarily contaminated the seaward edges of the wetlands (Figure 1). Several studies mapped the oil spill extent in the ocean [58-61] and the wetlands [62], and its detrimental effects on the wetland vegetation [20,22].

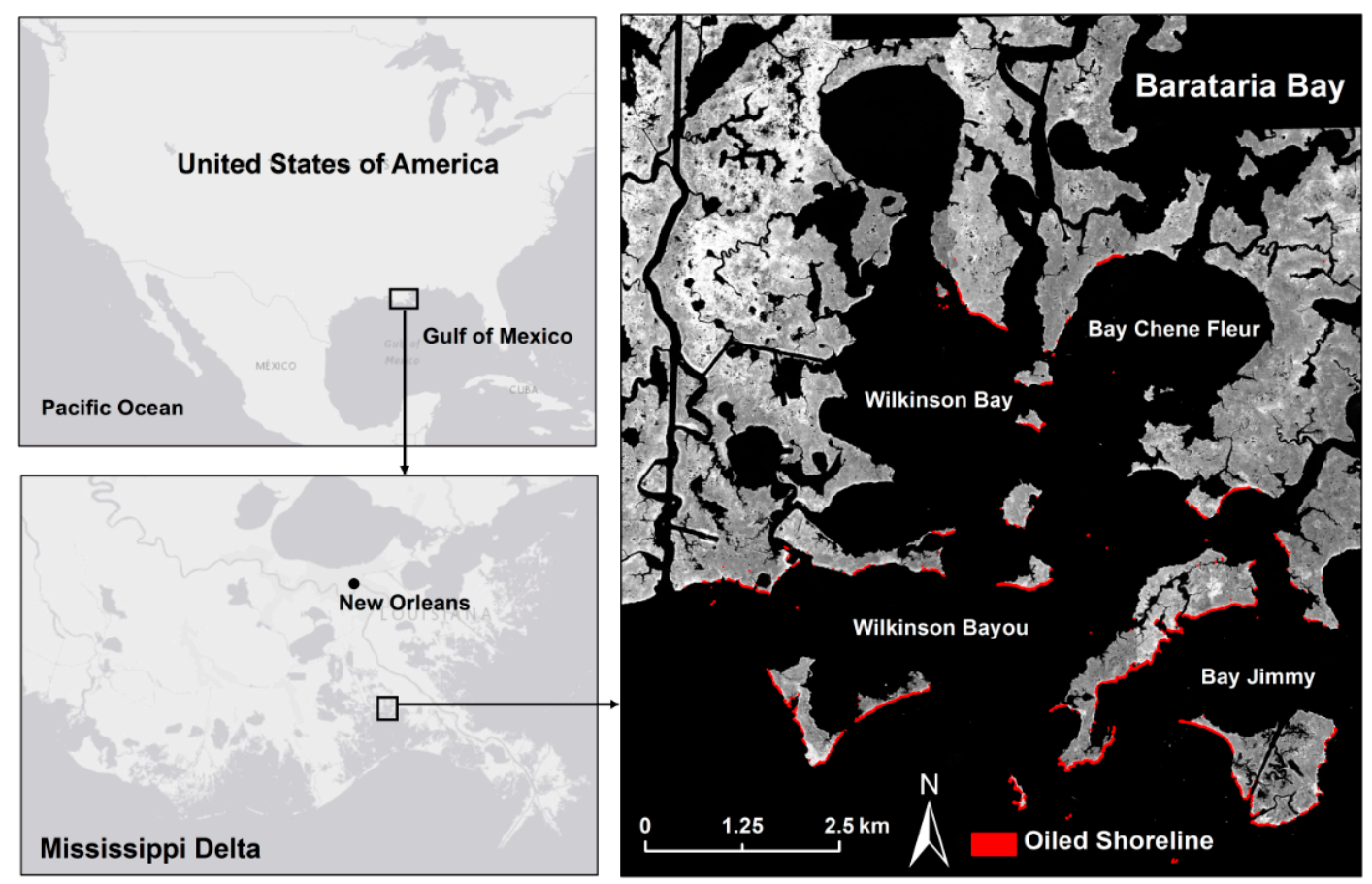

Figure 1. AVIRIS gray scale image of Barataria Bay and its location in the Mississippi Delta. Oil mapped using AVIRIS 2010 imagery is overlaid in red.

\subsection{Image Data and Preprocessing}

AVIRIS data was acquired over Barataria Bay and used to map the presence of oil along the wetland shoreline and to detect plant stress due to oil contamination on vegetation [20]. Four flight-lines covering an area of $175 \mathrm{~km}^{2}$ (Table 1) were georeferenced by NASA Jet Propulsion Laboratory using information derived from inertial navigation data and GPS. Unfortunately, images georeferenced based on this information often suffer from residual misalignment by a few pixels or more, and this misalignment translated into displacements of the order of dozens of meters, whereas oil penetration and impact was unequal near the shore exhibiting sharp gradients on the scale of just a few meters [20,63]. Hence the 2010 images were further georectified to $1 \mathrm{~m}$ National Agricultural Imagery Program (NAIP) color infrared images collected in 2010. Images were also atmospherically calibrated using the Atmospheric CORrection Now algorithm (ACORN) 6, mode 1.5 (ImSpec LLC, Seattle, WA, USA) to apparent surface reflectance.

Table 1. Characteristics of the four sensors and date of image acquisition for data analyzed in this study.

\begin{tabular}{ccccc}
\hline & AVIRIS & WorldView2 & Rapid Eye & Landsat ETM+ \\
\hline Bandwidth & $10-15 \mathrm{~nm}$ & $40-180 \mathrm{~nm}$ & $40-90 \mathrm{~nm}$ & $60-260 \mathrm{~nm}$ \\
Spatial resolution & $3.5 \mathrm{~m}$ & $2 \mathrm{~m}$ & $5 \mathrm{~m}$ & $15 \mathrm{~m}, 30 \mathrm{~m}$ \\
Radiometric resolution & $16-$ bit & $11-$ bit & 16 -bit & 8 -bit \\
Time of acquisition & 19 September 2010 & 8 September 2010 & 8 October 2010 & 13 September 2010 \\
Signal-to-noise ratio & $800-1200[64]$ & $250-500[65]$ & $90-140[66,67]$ & $20-55[64,68]$ \\
Cloud cover & $0 \%$ & $30 \%$ & $0 \%$ & $0 \%$ \\
\hline
\end{tabular}


Seventeen multispectral WorldView2 images (Table 1) covering the same area as AVIRIS were atmospherically calibrated to apparent surface reflectance and mosaicked. Two RapidEye images were also calibrated to apparent surface reflectance and mosaicked. Finally, one Landsat ETM+ image was calibrated to apparent surface reflectance using ACORN 6, mode 5. Since both WorldView2 and RapidEye data were acquired off-nadir, we could not use ACORN for atmospheric correction. Hence we used Atmospheric Correction and Haze Reduction (ATCOR) [69] which allows input of non-nadir view angles. Moreover, it performs at least as well as ACORN and the results of the two calibration techniques are comparable, especially over a flat terrain such as Barataria Bay [70].

All images from the three multispectral sensors were subset to the spatial extent of the oil-affected section of the study area (Figure 2, $86 \mathrm{~km}^{2}$ ). Both WorldView2 and RapidEye image mosaics were further co-registered to the AVIRIS 2010 imagery using an automated image registration technique [71,72] to enable comparisons between the different sensors. The advantage of this technique is that areas of spurious change can be excluded, e.g., clouds in one image or shoreline changes with varying tidal stage. We were able to exclude these areas from calculations of displacement between images, hence the tidal stages of different images did not affect the accuracy of co-registration.

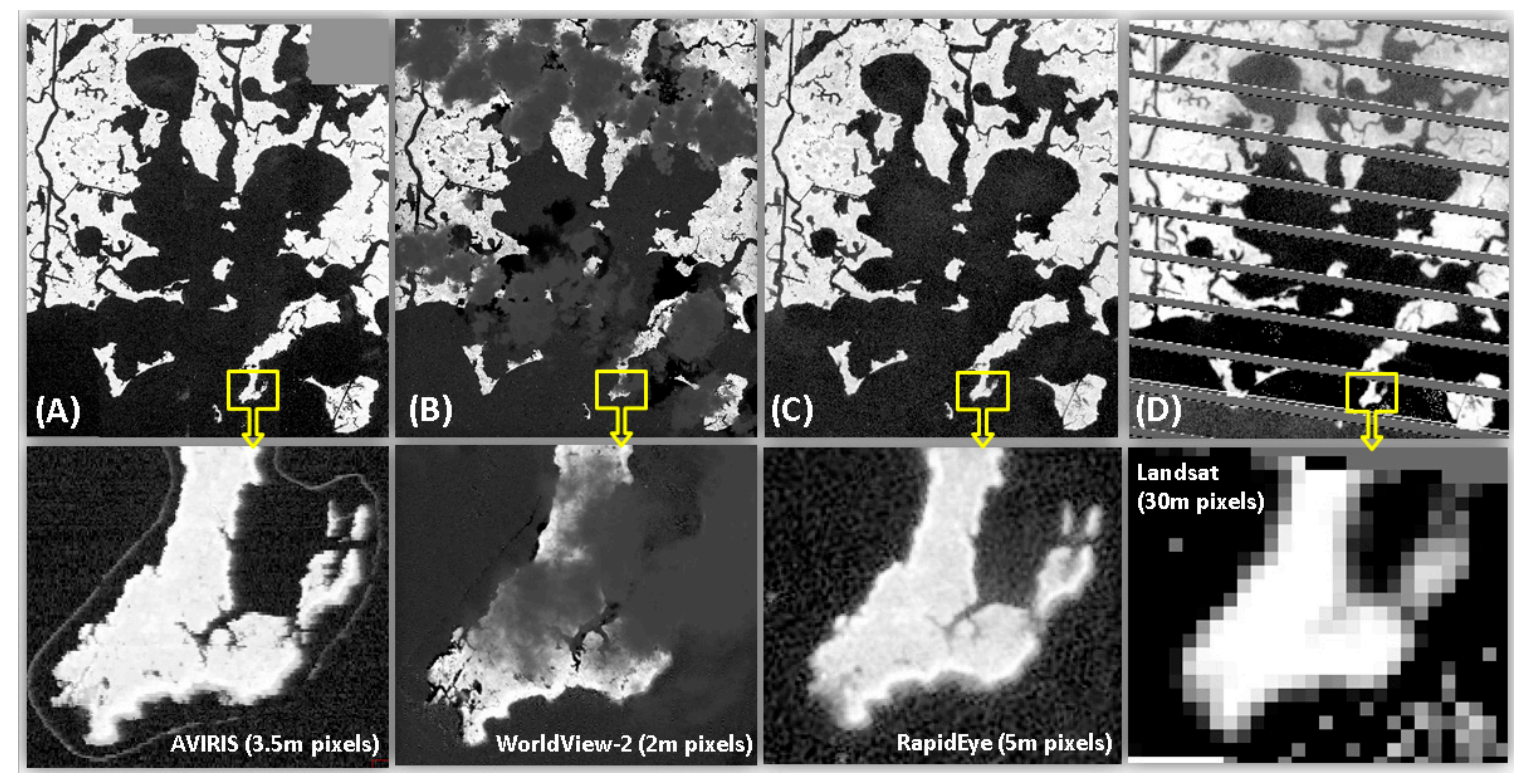

Figure 2. Barataria Bay gray scale image subset for all four sensors and a close view of a smaller region to highlight differences in image quality and spatial resolution (A) AVIRIS $3.5 \mathrm{~m}$ imagery, (B) WorldView2 2 m imagery, (C) RapidEye 5 m imagery, and (D) Landsat ETM+ 30 m imagery.

We mapped oil on exposed soil surfaces and dry vegetation, and water and land pixels in the AVIRIS 2010 images using a binary decision tree following methods in Khanna et al. [73]. Inputs to the decision tree included vegetation and angle indices and continuum removals [74] over two well-known oil absorption features centered at $2100 \mathrm{~nm}$ and $2300 \mathrm{~nm}$ [62]. Binary classes, land and water, were mapped in addition to oiled pixels.

The United States Geological Survey (USGS) conducted field data surveys in Barataria Bay on 10 July 2010 and again on 12-13 August 2010 [63]. At each $2 \times 2 \mathrm{~m}$ survey point, they collected information on the vegetation species composition, canopy condition, presence of oil, and penetration of oil into the marsh. We randomly chose half the points for training the classifier to recognize oiled pixels and the other half to test the accuracy of detecting oiled pixels using Kappa statistics, and overall classification accuracy $[75,76]$. The results of this classification were first presented in Khanna et al. [20] showing that the oiled pixels were classified with an overall accuracy of $95 \%$ and a Kappa of 0.88 . 


\subsection{Methods}

\subsubsection{AVIRIS Hyperspectral Data}

To compare the effect of sensor spectral and spatial resolution on detecting plant stress, we spectrally resampled AVIRIS hyperspectral data to simulate the WorldView2, RapidEye, and Landsat ETM+ sensors using pre-defined filter functions available in ENVI 4.8 (ITT Visual Information Solutions). Next, we resampled the simulated images to the spatial resolution of these sensors, $5 \mathrm{~m}$ for RapidEye and $30 \mathrm{~m}$ for Landsat ETM+, using pixel aggregate and bilinear convolution methods when appropriate in ENVI 4.8. We pan-sharpened the $30 \mathrm{~m}$ simulated Landsat imagery to $15 \mathrm{~m}$ spatial resolution using the Gram-Schmidt pan-sharpening method available in ENVI 4.8 [77]. Since the spatial resolution of the original AVIRIS imagery was $3.5 \mathrm{~m}$ and it is technically impossible to get better resolution imagery by resampling a coarser resolution image, we did not recreate the $2 \mathrm{~m}$ WorldView2 resolution for the simulated WorldView2 imagery. We will refer to these resampled image data in our study as AVIRIS $_{W V 2}$, AVIRIS $_{R E}$, AVIRIS $_{\text {LS-30m }}$ and AVIRIS $_{\text {LS-15m. }}$.

\subsubsection{Multispectral Sensor Data}

In addition to varying spatial and spectral resolution, sensors also differ in other characteristics, such as lens distortion and signal-to-noise parameters, which can affect their performance in measuring the phenomena of interest $[64,66]$. Hence, the next step in our study was to compare the ability to detect oil-induced vegetation stress from images acquired by WorldView2, RapidEye, and Landsat 7 ETM+ sensors to that of the AVIRIS image using dates as close to the AVIRIS image date as was available. The WorldView2 and Landsat images were acquired within a week of the AVIRIS image acquisition date while the RapidEye image was within a month of that date (Table 1). The Landsat ETM+ image was further pan-sharpened to $15 \mathrm{~m}$ pixel resolution using the Gram-Schmidt pan-sharpening method available in ENVI 4.8 [77]. Figure 3 illustrates the different spectral resolutions of the four sensors.

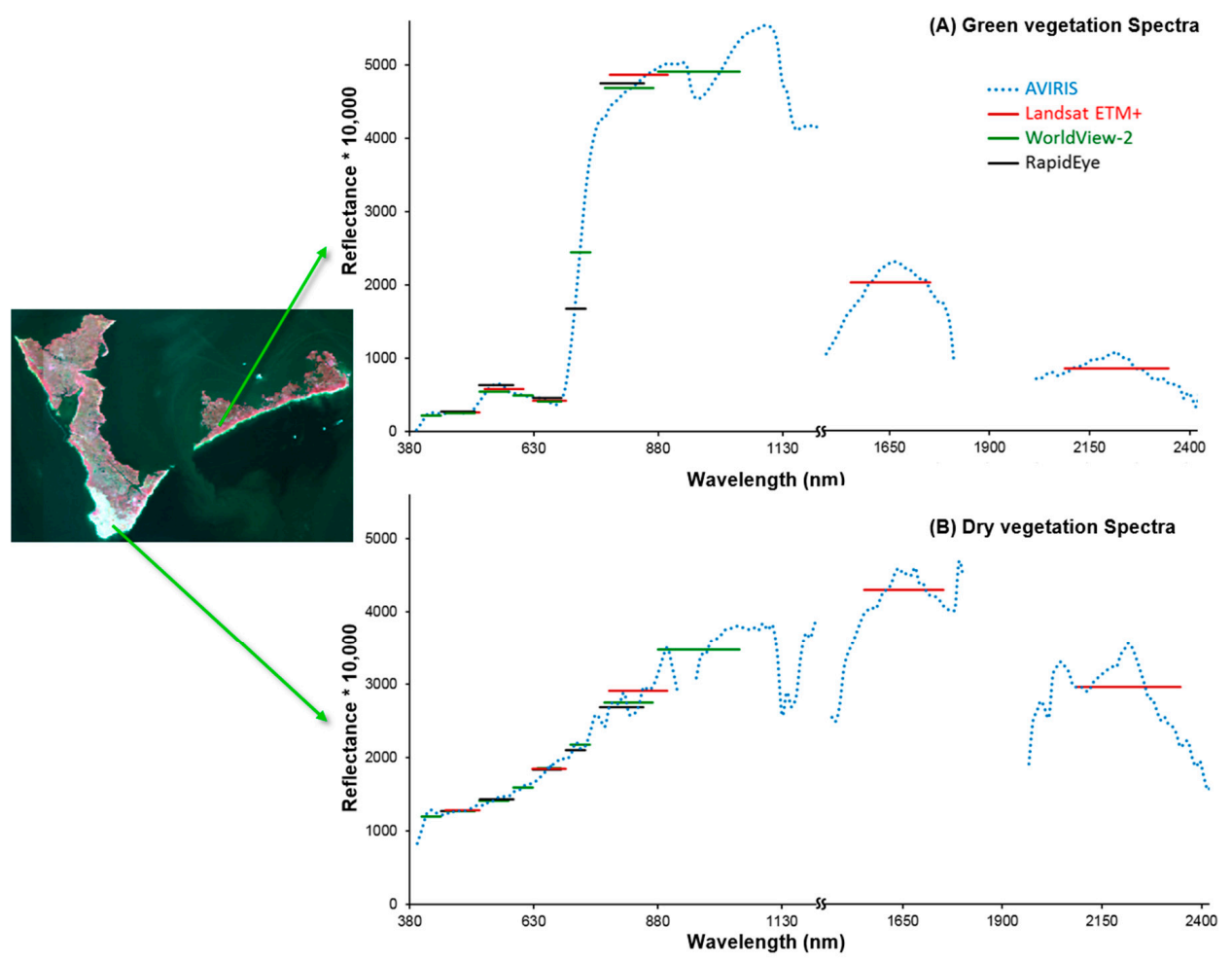

Figure 3. An example of (A) green vegetation and (B) non-photosynthetic vegetation (NPV) pixel spectra from AVIRIS, WorldView2, RapidEye, and Landsat ETM+ showing the range and spectral resolution of the sensors. 


\subsubsection{Selection of Oiled and Oil-Free Areas}

We followed a consistent procedure to assign shorelines as either oiled or oil-free and extract pixels along those shorelines for analysis. First, based on the classification of the 2010 AVIRIS image dataset, we used the boundary of the land and water classes to produce a vector layer of the shoreline. Next, sections of the shore with oiled pixels adjacent to them were considered as oiled shoreline. Sections of shore next to oil-free pixels were considered as oil-free shoreline. Only oil-free shoreline within $140 \mathrm{~m}$ of an oiled shoreline was used for comparison to ensure that the sites used were as similar to each other as possible, except in the degree of oiling. Finally, we extracted all pixels within $60 \mathrm{~m}$ perpendicular to and inland from shore of the selected shorelines compare vegetation stress between oiled and oil-free shorelines.

We subdivided the extracted pixels from the images into zones parallel to the shoreline. A zone is defined as the line of pixels parallel to the shore where each pixel within that zone is away from the shore by the same distance measured in pixel width. For example, zone 1 corresponds to the first pixel adjacent to the shore, zone 2 corresponds to two pixels from the shore, and so on. The width of the zones was determined by the image pixel size. We chose to compare corresponding zones parallel to the shoreline because wetland species distributions, abundance and changes in composition follow elevation gradients [78]. In the gulf wetlands the remote sensing data reveals an inherent spatial pattern irrespective of other impacts: vegetation is moderately dense in the intertidal zone followed by a band of more dense and green vegetation that occurs just beyond the intertidal zone, and then slightly lower density in the inner marsh [20]. Thus by comparing within zones, we minimized the confounding effects of these inherent spatial patterns in wetland vegetation communities.

\subsubsection{Detection of Vegetation Stress}

We calculated four vegetation indices based on the Green, Red, NIR and SWIR bands: Normalized Difference Vegetation Index (NDVI), Normalized Difference Infrared Index (NDII), Angle at Near InfraRed (ANIR) and Angle at Red (ARed; Table 2). The bandwidth and wavelength centers of the bands in these general electromagnetic regions were dependent on the sensor specifications, e.g., while AVIRIS had narrow 10-15 nm bands, the three multi-spectral sensors had much broader

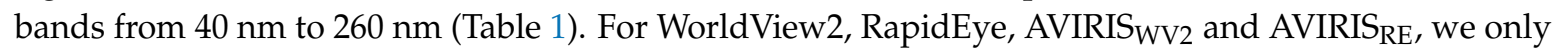
calculated NDVI and ARed since both ANIR and NDII require a SWIR band, which WorldView2

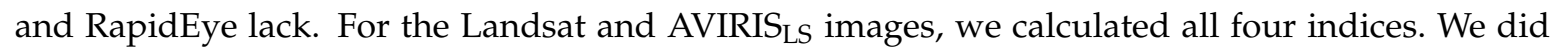
not radiometrically calibrate the different sensor images because our comparisons are between pixels of the same image rather than between sensors. The purpose is to compare the ability of sensors to differentiate healthy vegetation from stressed vegetation within the same image and this can be done effectively by using a statistical approach that is independent of the range and magnitude of index values and then comparing the statistic across sensors.

Table 2. Vegetation indices used to test for the effects of oil contamination on vegetation stress, and the sensors they were calculated for. $R_{G}, R_{R}, R_{N I R}$ and $R_{S W I R}$ are the reflectance values in the Green $(G)$, Red (R), Near InfraRed (NIR) and ShortWave InfraRed (SWIR) bands respectively and $\lambda_{\mathrm{G}}(550-570 \mathrm{~nm})$, $\lambda_{\mathrm{R}}(650 \mathrm{~nm}), \lambda_{\mathrm{NIR}}(805-840 \mathrm{~nm})$ and $\lambda_{\mathrm{SWIR}}(1650 \mathrm{~nm})$ are the wavelength values at the band centers.

\begin{tabular}{ccccc}
\hline Inputs & Formula & Relevance & $\begin{array}{c}\text { References } \\
\text { Using Sensors }\end{array}$ & $\begin{array}{c}\text { Index Calculated } \\
\text { Using }\end{array}$ \\
\hline $\begin{array}{c}\text { Normalized Difference } \\
\text { Vegetation Index (NDVI) }\end{array}$ & $\frac{R_{N I R}-R_{R}}{R_{N I R}+R_{R}}$ & $\begin{array}{c}\text { Index of green plant cover } \\
\text { and LAI }\end{array}$ & [46,47] & AVIRIS \\
\hline $\begin{array}{c}\text { Normalized Difference } \\
\text { Infrared Index (NDII) }\end{array}$ & $\frac{R_{N I R}-R_{S W I R}}{R_{N I R}+R_{S W I R}}$ & $\begin{array}{c}\text { Sensitive to plant } \\
\text { water content }\end{array}$ & {$[43,79]$} & AVIRIS, Landsat \\
\hline $\begin{array}{c}\text { Angle at NIR } \\
\text { (ANIR) }(\mathrm{rad})\end{array}$ & $\begin{array}{c}\text { Angle between }\left(\mathrm{R}_{\mathrm{R}}, \lambda_{\mathrm{R}}\right),\left(\mathrm{R}_{\mathrm{NIR}},\right. \\
\left.\lambda_{\mathrm{NIR}}\right), \text { and }\left(\mathrm{R}_{\mathrm{SWIR}}, \lambda_{\mathrm{SWIR}}\right)\end{array}$ & $\begin{array}{c}\text { Angle index sensitive to } \\
\text { change in land cover type }\end{array}$ & {$[44,80]$} & AVIRIS \\
\hline $\begin{array}{l}\text { Angle at Red } \\
\text { (ARed) }(\mathrm{rad})\end{array}$ & $\begin{array}{c}\text { Angle between }\left(\mathrm{R}_{\mathrm{G}}, \lambda_{\mathrm{G}}\right),\left(\mathrm{R}_{\mathrm{R}},\right. \\
\left.\lambda_{\mathrm{R}}\right), \text { and }\left(\mathrm{R}_{\mathrm{NIR}}, \lambda_{\mathrm{NIR}}\right)\end{array}$ & $\begin{array}{c}\text { Angle index sensitive to plant } \\
\text { pigments and land cover type }\end{array}$ & $\begin{array}{c}{[20,80]} \\
\text { AVIRIS, WorldView2, } \\
\text { RapidEye, Landsat }\end{array}$ \\
\hline
\end{tabular}


Effect size is a statistic that measures the degree of overlap between the frequency distributions of two samples; if the frequency distributions overlap it suggests the two samples come from the same population i.e., are not differentiable, while when there is little or no overlap, it suggests that the two samples are not from the same population. The greater the overlap in the frequency distributions, the lower the effect size and vice versa. Effect size is a good metric because it is independent of sample size and the range of index values. To determine differences in plant stress along oiled vs. oil-free shorelines, we first tested whether average index values were different in pixels alongside oiled and oil-free shorelines by using a $t$-test [81]. To assess the magnitude of the differences in index values, we calculated the effect size, Cohen's d [82]. Cohen's d is a standardized metric of the difference between two means as it divides the population mean by the pooled standard deviation, allowing for comparisons across many variables and sensors [82,83]. A Cohen's d value of 0.8 indicates a strong effect, i.e., little overlap between the two frequency distributions suggesting a strong ability to differentiate between the two samples, a value of 0.5 indicates a moderate effect, while a value lower than 0.2 indicates a weak effect [82].

\section{Results}

\subsection{AVIRIS Hyperspectral Data}

The first $14 \mathrm{~m}$ (4 pixels) along the oiled shore in the AVIRIS hyperspectral imagery have significantly more stressed vegetation than the corresponding oil-free zone. All indices had significantly lower values (ANIR has the reverse order with higher values indicating lower stress) along the oiled shoreline relative to the oil-free shore line, (Table 3). Despite all zones showing significant differences in index values, the effect size decreased as we moved inland from the shore indicating that oil-induced vegetation stress decreased away from the shore (Table 3).

While all four indices detect plant stress effectively, ARed (average Cohen's d = 0.81) and NDII (average Cohen's $d=0.80$ ) exhibited the strongest effect sizes, thus performing better at differentiating vegetation stress due to oil contamination. In the first zone, where the oil impact was expected to be maximum, average value of ARed dropped from 5.12 along oil-free shores to 4.11 along oiled shorelines, while average value of NDII dropped from 0.51 to 0.33 (Table 3). Hence, we selected ARed for a comparison of all four sensors and NDII for an additional comparison of Landsat ETM+ and AVIRIS.

Table 3. Student $t$-test comparison results for four indices calculated with AVIRIS data. Value of Cohen's d indicates effect size.

\begin{tabular}{|c|c|c|c|c|c|c|c|c|c|c|}
\hline \multirow{2}{*}{ Index } & \multirow{2}{*}{ Zone } & \multicolumn{2}{|c|}{$\mathbf{N}$} & \multicolumn{2}{|c|}{ Mean } & \multicolumn{2}{|c|}{ Std. Dev. } & \multirow{2}{*}{$\begin{array}{c}\text { Student } \\
t \text {-Statistic }\end{array}$} & \multirow{2}{*}{$p$-Value } & \multirow{2}{*}{ Cohen's d } \\
\hline & & Oiled & $\overline{\text { Oil-Free }}$ & Oiled & Oil-Free & Oiled & $\overline{\text { Oil-Free }}$ & & & \\
\hline \multirow{3}{*}{ NDVI } & 1 & 5539 & 3156 & 0.474 & 0.583 & 0.223 & 0.227 & -21.560 & 0.000 & 0.483 \\
\hline & 2 & 5220 & 3118 & 0.618 & 0.676 & 0.178 & 0.192 & -13.614 & 0.000 & 0.314 \\
\hline & 3 & 3941 & 2440 & 0.683 & 0.711 & 0.159 & 0.153 & -6.933 & 0.000 & 0.177 \\
\hline \multirow{4}{*}{ ARed } & 1 & 5539 & 3156 & 4.113 & 5.118 & 0.796 & 0.760 & -58.320 & 0.000 & 1.284 \\
\hline & 2 & 5220 & 3118 & 4.596 & 5.287 & 0.944 & 0.752 & -36.862 & 0.000 & 0.789 \\
\hline & 3 & 3941 & 2440 & 5.122 & 5.397 & 0.834 & 0.665 & -14.585 & 0.000 & 0.357 \\
\hline & 4 & 3841 & 2533 & 5.399 & 5.449 & 0.670 & 0.593 & -3.088 & 0.002 & 0.077 \\
\hline \multirow{4}{*}{ NDII } & 1 & 5539 & 3156 & 0.333 & 0.510 & 0.172 & 0.155 & -49.431 & 0.000 & 1.072 \\
\hline & 2 & 5220 & 3118 & 0.395 & 0.531 & 0.172 & 0.132 & -40.495 & 0.000 & 0.858 \\
\hline & 3 & 3941 & 2440 & 0.484 & 0.548 & 0.151 & 0.121 & -18.691 & 0.000 & 0.457 \\
\hline & 4 & 3841 & 2533 & 0.539 & 0.561 & 0.125 & 0.113 & -7.118 & 0.000 & 0.179 \\
\hline \multirow{4}{*}{ ANIR } & 1 & 5539 & 3156 & 1.531 & 0.775 & 0.849 & 0.708 & 44.471 & 0.000 & 0.944 \\
\hline & 2 & 5220 & 3118 & 0.940 & 0.503 & 0.802 & 0.554 & 29.361 & 0.000 & 0.608 \\
\hline & 3 & 3941 & 2440 & 0.584 & 0.424 & 0.601 & 0.425 & 12.500 & 0.000 & 0.298 \\
\hline & 4 & 3841 & 2533 & 0.461 & 0.422 & 0.484 & 0.411 & 3.376 & 0.001 & 0.084 \\
\hline
\end{tabular}




\subsubsection{Spectral Resolution}

Comparing the ability to detect oil-induced stress in vegetation using AVIRIS ${ }_{W V 2}$ vs. AVIRIS data shows the effect of spectral resolution on oil impact detection. We found that effect size for ARed decreased about $12 \%$ from AVIRIS narrow-band imagery (average for zones $1-3$, Cohen's $d=0.81$ ) to AVIRIS $_{W V 2}$ broad-band imagery (average for zones $1-3$, Cohen's $d=0.71$ ) (Table 4 ). In the fourth zone from the shore, ARed values between oiled and oil-free shorelines were no longer significantly different using AVIRIS ${ }_{W V 2}$ data while they were still significant using AVIRIS data (Table 4). Thus, the reduced spectral resolution of the AVIRIS ${ }_{\mathrm{WV} 2}$ resulted in a lower ability to discriminate vegetation stress in the most oiled zones, and a lack of differentiation potential in the zone, $14 \mathrm{~m}$ inland from shoreline (Table 4).

Table 4. Student $t$-test comparison results for ARed in radians calculated from AVIRIS narrow-band

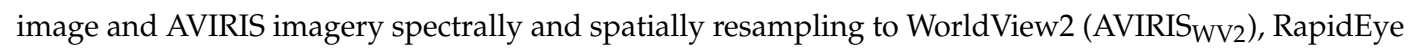
$\left(\right.$ AVIRIS $_{\text {RE }}$ ), and Landsat (AVIRIS $\left.{ }_{\text {LS }}\right) 15 \mathrm{~m}$ and $30 \mathrm{~m}$. Value of Cohen's d indicates effect size.

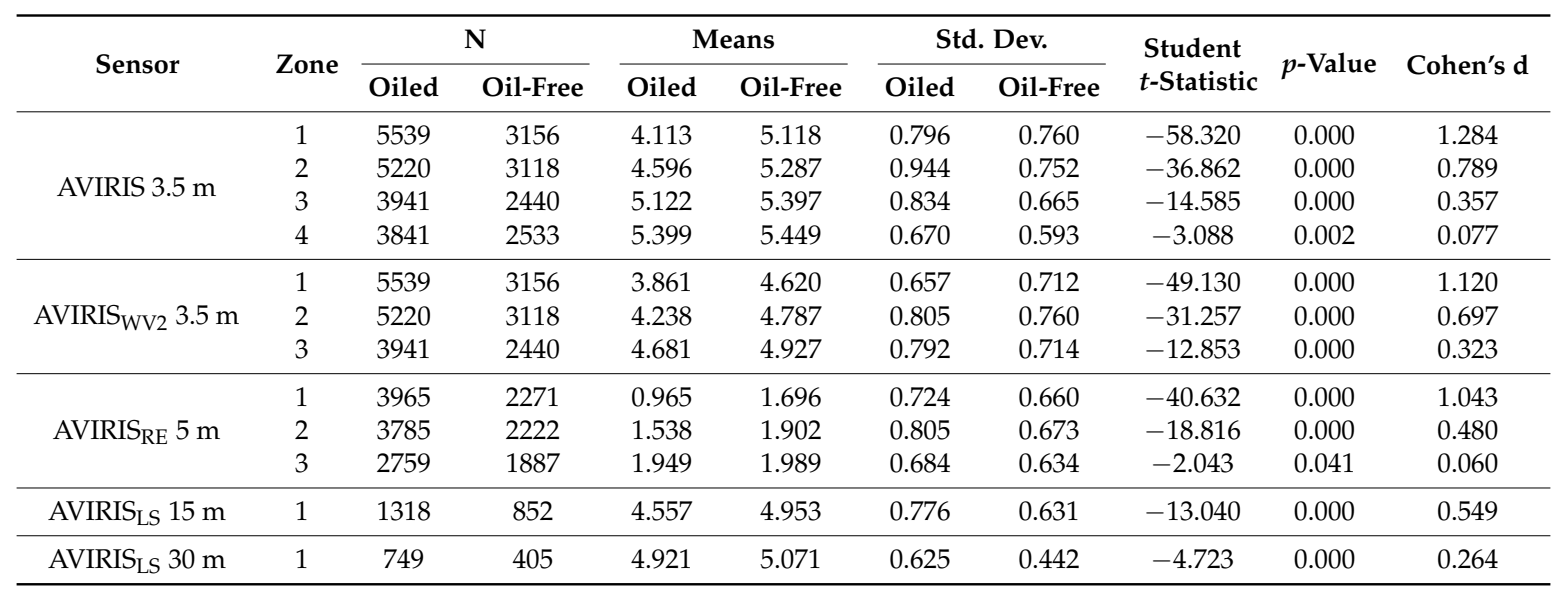

\subsubsection{Spatial Resolution}

AVIRIS, AVIRIS $S_{\text {RE, }}$ AVIRIS $S_{\text {LS-15m }}$ and AVIRIS $_{\text {LS-30m }}$ represent progressively coarser spatial resolutions from $3.5 \mathrm{~m}$ to $5 \mathrm{~m}$ to $15 \mathrm{~m}$ to $30 \mathrm{~m}$ pixels. Comparing the performance of the four image datasets showed that loss of spatial resolution resulted in especially low effect sizes, i.e., decreased ability to detect differences in vegetation index values. A comparison of the first zone next to the shore shows effect sizes dropped one order of magnitude, from 1.12 to 0.19 , as spatial resolution became coarser from $3.5 \mathrm{~m}$ AVIRIS $_{\mathrm{WV} 2}$ to $5 \mathrm{~m}_{\text {AVIRIS }}$ RE to $15 \mathrm{~m}_{\text {AVIRIS }}$ LS to $30 \mathrm{~m}_{\text {AVIRIS }}$ (Figure 4; Table 4). For example, the effect size for AVIRIS ${ }_{\text {LS }}$ dropped by half, from 0.55 in the $15 \mathrm{~m}$ pixel image to 0.26 in the $30 \mathrm{~m}$ pixel image, indicating that the area of overlap between the oiled and oil-free index frequency distributions increased considerably.

While all four spatial resolutions were sufficient to detect significant vegetation stress in the pixels located largely within the $14 \mathrm{~m}$ zones next to the oiled shoreline, the sensitivity of that detection reduced quickly with increasing pixel size. The zone of oil impact became less defined as zones became more mixed (Figure 5). 


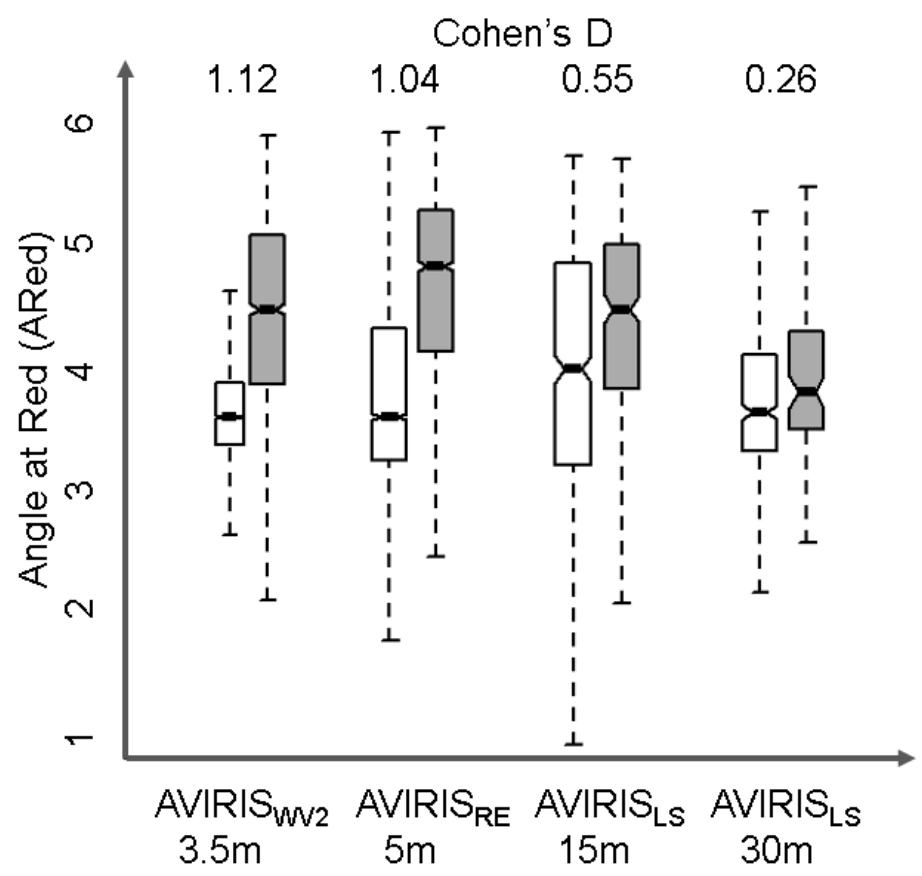

Figure 4. Boxplots of the Angle at Red index in the first pixel zone along oiled (white) vs. oil-free (gray) shoreline using AVIRIS imagery resampled to WorldView2, Landsat ETM+ $15 \mathrm{~m}$ and Landsat ETM+ $30 \mathrm{~m}$. Notches on the boxplots indicate the $95 \%$ confidence interval. Cohen's d values are shown for reference at the top.

A. AVIRIS
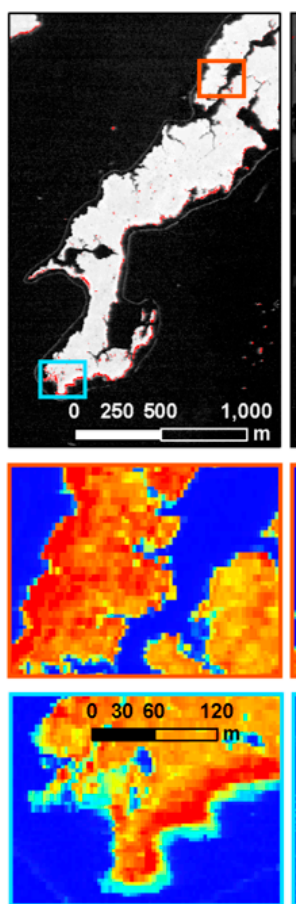

C. RapidEye
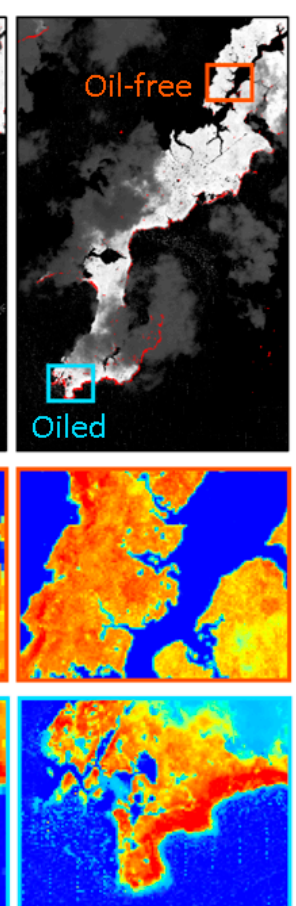
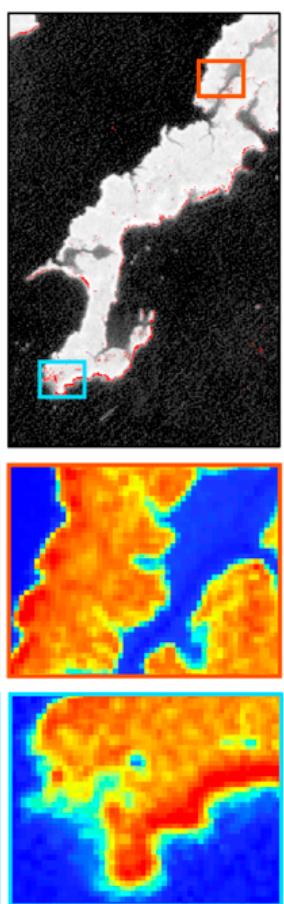

D. Landsat $15 \mathrm{~m}$
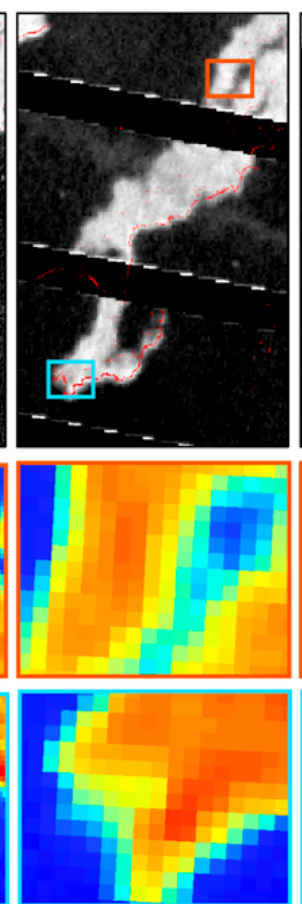

E. Landsat $30 \mathrm{~m}$
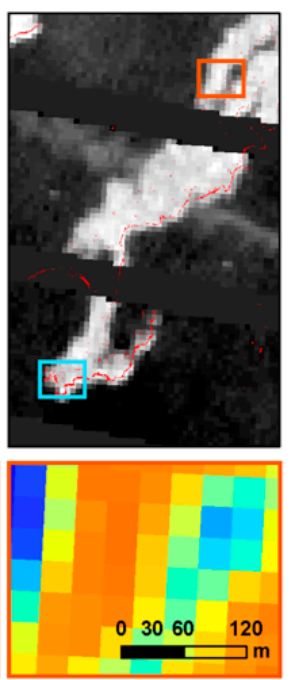

NDVI

High

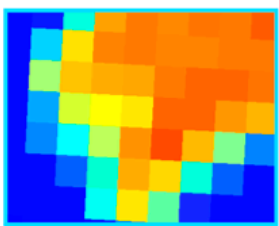

Figure 5. A subset of Barataria Bay shown in gray scale (A) AVIRIS, (B) WorldView-2, (C) RapidEye, (D) Landsat ETM+ pan sharpened $15 \mathrm{~m}$, (E) Landsat ETM+ $30 \mathrm{~m}$ with oiled pixels overlaid in red. NDVI color map of an oiled and an oil-free area is detailed in the second and third rows from the top. Note the lack of spatial definition of the affected area as spatial resolution deteriorates. 


\subsection{Multispectral Data}

All three multispectral sensors, WorldView2, RapidEye and Landsat ETM+, performed worse than the AVIRIS imagery resampled to the spatial and spectral resolution of these sensors (Table 5). Using original WorldView2 imagery, we were able to detect significant differences in index values along oiled vs. oil-free shorelines in zones up to $10 \mathrm{~m}$ inland (5 pixels; Table 5), which is similar to the $10.5 \mathrm{~m}$ distance over which significant differences were observed for AVIRIS ${ }_{W V 2}$. However, the effect sizes for WorldView2 data were lower than those for $\mathrm{AVIRIS}_{\mathrm{WV} 2}$ data indicating weaker differentiation in vegetation index values. The RapidEye imagery could only detect impact $5 \mathrm{~m}$ inland (1 pixel), while AVIRIS $S_{\text {RE }}$ detected oil impact up to $15 \mathrm{~m}$ (3 pixels). Again, the RapidEye effect size was less than half that of AVIRIS $S_{R E}$ for the corresponding zone (Figure 6, Table 5). Similarly, for Landsat, effect sizes

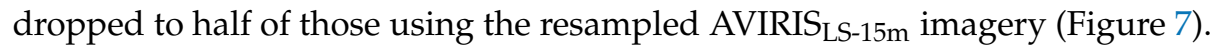

Landsat comparisons using NDII also showed that AVIRIS LS-15m $_{\text {imagery produced higher effect }}$ sizes than the pan-sharpened Landsat ETM+ $15 \mathrm{~m}$ imagery (Table 6). For the Landsat $30 \mathrm{~m}$ image, we found no significant differences among oiled and oil-free shores while the AVIRIS ${ }_{\mathrm{LS}^{-}}-30 \mathrm{~m}$ was still able to differentiate oiled conditions for the first $30 \mathrm{~m}$ inland (1 pixel).
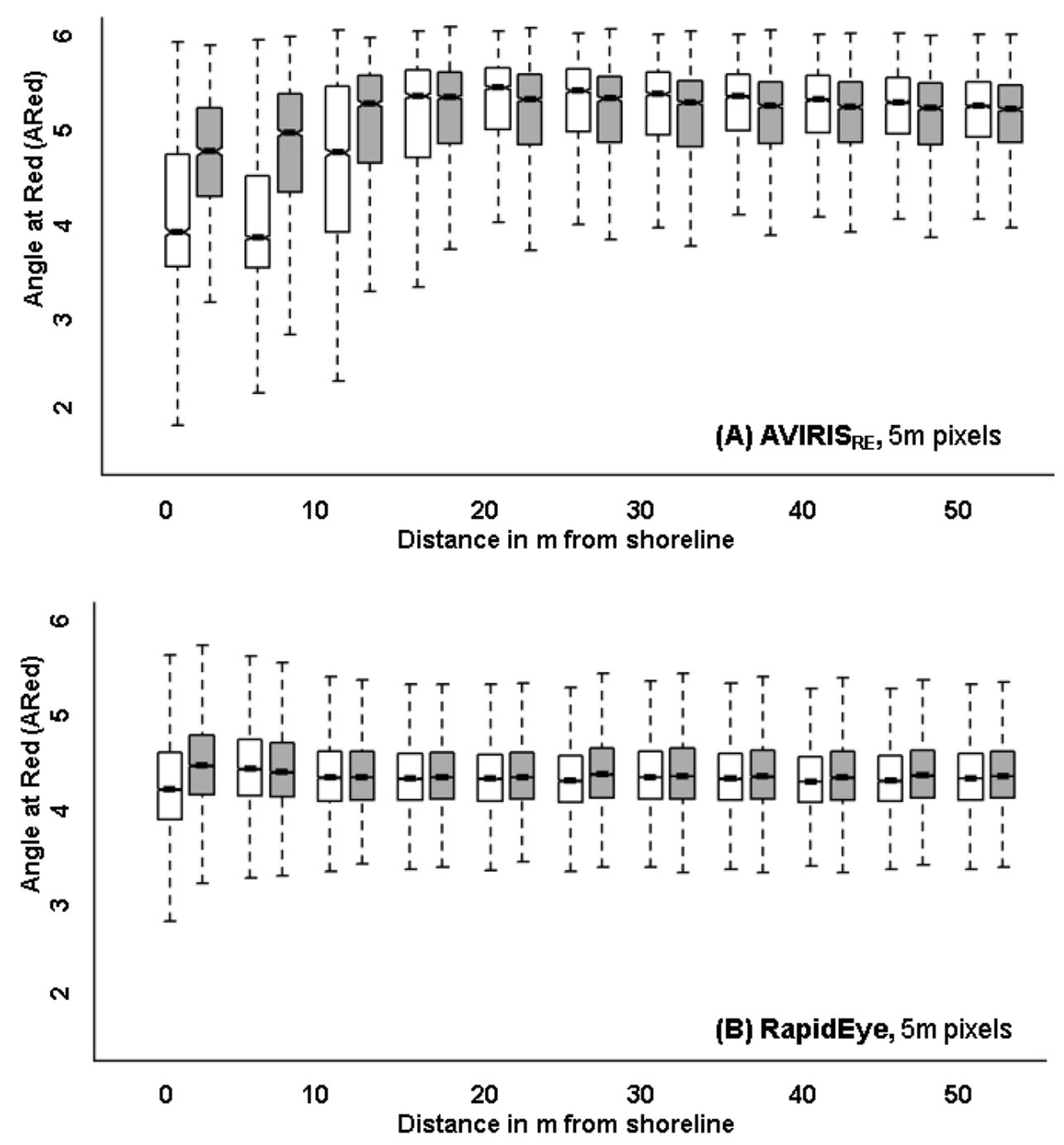

Figure 6. Angle at Red vs. distance from shoreline in meters for (A) AVIRIS resampled to RapidEye and (B) actual RapidEye imagery. Distribution of the index along the oiled shoreline is in white and along oil-free shoreline, in gray. 
(A) AVIRIS resampled to Landsat ETM+15m

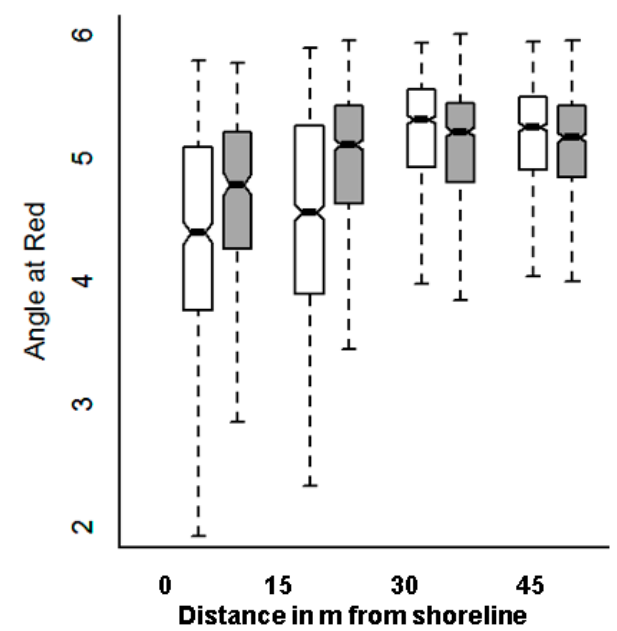

(B) Pan-sharpened Landsat ETM+15m

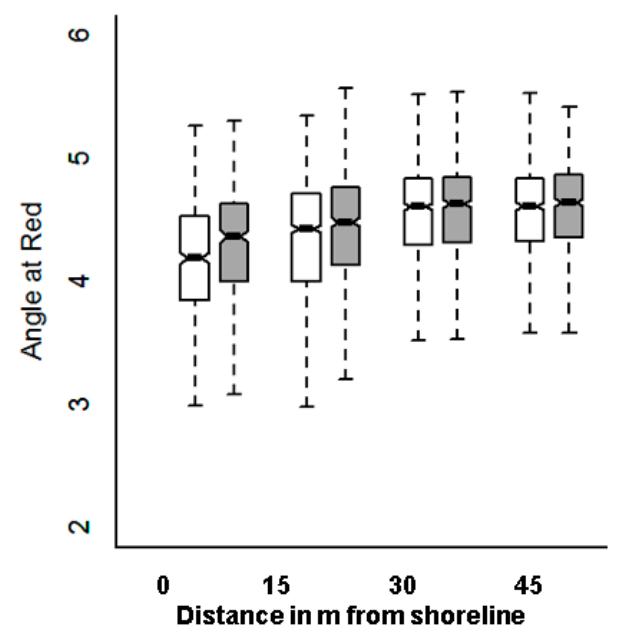

Figure 7. Angle at Red vs. distance from shoreline in meters for (A) AVIRIS resampled to Landsat $15 \mathrm{~m}$ and (B) actual Landsat ETM+ $15 \mathrm{~m}$ pan-sharpened imagery. Distribution of the index along the oiled shoreline is in white and along oil-free shoreline is in gray.

Table 5. Student $t$-test comparison results for ARed in radians calculated from AVIRIS imagery spectrally and spatially resampled to WorldView2 (AVIRIS ${ }_{W V 2}$ ), RapidEye (AVIRIS RE$_{\text {), Landsat }}$ (AVIRIS $\left._{\mathrm{LS}}\right) 15 \mathrm{~m}$ and $30 \mathrm{~m}$ compared to the actual sensor imagery. Value of Cohen's d indicates effect size.

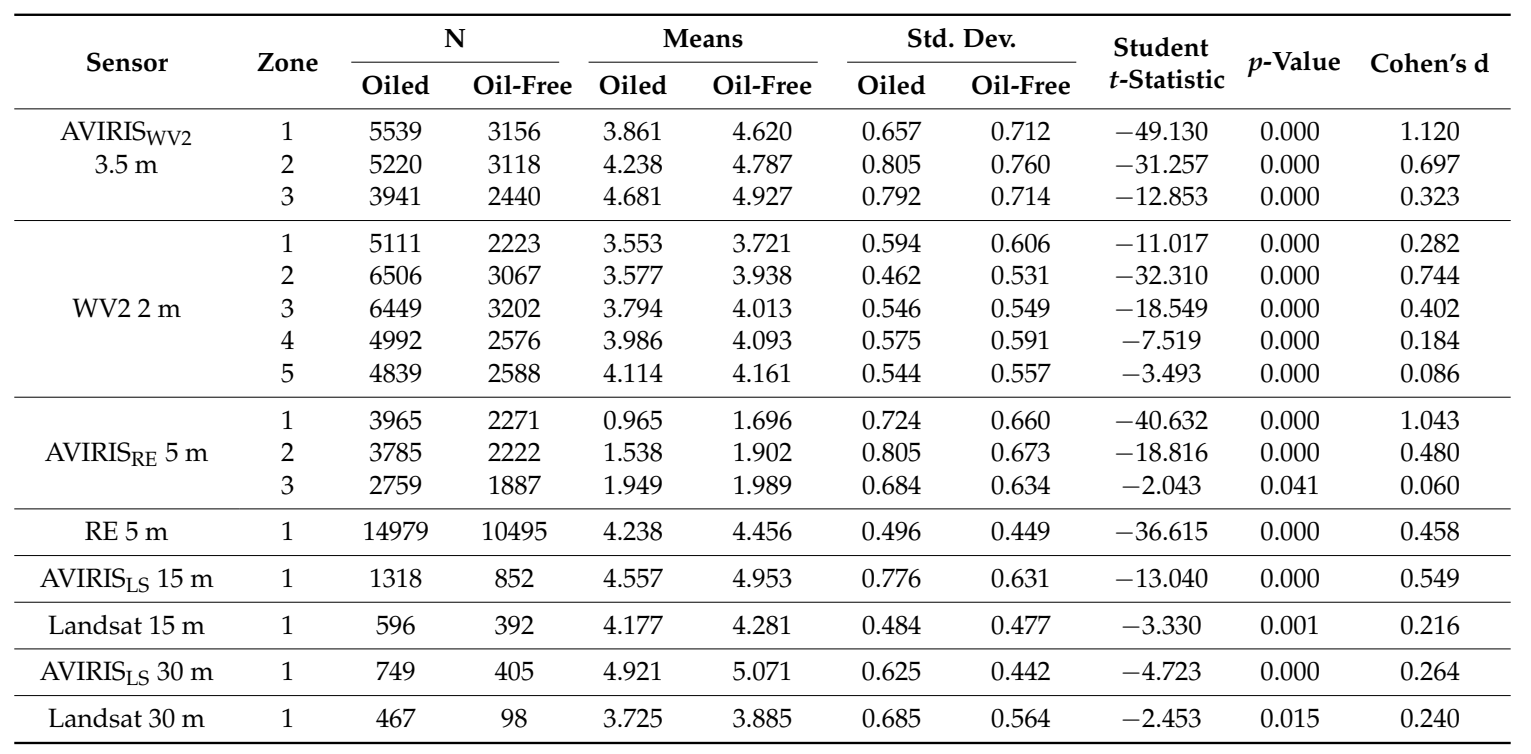

Table 6. Student $t$-test comparison results for NDII calculated from AVIRIS imagery spectrally and spatially resampled to Landsat (AVIRIS LS $_{\text {) }} 15 \mathrm{~m}$ and $30 \mathrm{~m}$ compared to the actual Landsat imagery. Value of Cohen's d indicates effect size.

\begin{tabular}{|c|c|c|c|c|c|c|c|c|c|c|}
\hline \multirow{2}{*}{ Sensor } & \multirow{2}{*}{ Zone } & \multicolumn{2}{|c|}{$\mathbf{N}$} & \multicolumn{2}{|c|}{ Means } & \multicolumn{2}{|c|}{ Std. Dev. } & \multirow{2}{*}{$\begin{array}{l}\text { Student } \\
t \text {-Statistic }\end{array}$} & \multirow{2}{*}{$p$-Value } & \multirow{2}{*}{ Cohen's d } \\
\hline & & Oiled & Oil-Free & Oiled & Oil-Free & Oiled & Oil-Free & & & \\
\hline AVIRIS $_{\mathrm{LS}} 15 \mathrm{~m}$ & 1 & 1318 & 852 & 0.431 & 0.540 & 0.172 & 0.130 & 16.772 & 0.000 & 0.695 \\
\hline AVIRIS $_{\text {LS }} 30 \mathrm{~m}$ & 1 & 749 & 405 & 0.498 & 0.553 & 0.120 & 0.100 & -8.359 & 0.000 & 0.489 \\
\hline Landsat $30 \mathrm{~m}$ & 1 & 467 & 98 & 0.254 & 0.397 & 0.422 & 0.907 & -1.517 & 0.132 & * \\
\hline
\end{tabular}

* Cohen's d not reported for Landsat ETM+ $30 \mathrm{~m}$ image because the $p$-value is not significant. 


\section{Discussion}

Selecting the appropriate remote sensing data to detect and monitor impacts of oil spills and recovery involves a careful consideration of cost and ability to achieve goals as no single sensor meets all the requirements needed for achieving such a task. Here, we set out to assess whether sensor spatial and spectral resolution, and sensor characteristics influence the ability to detect and map vegetation stress and mortality due to oil spills.

However, before we can assess vegetation stress, it is important to have a method to distinguish stress due to oiling from stress due to other causes such as hurricanes, drought, etc. Vegetation responds to completely different stress factors such as drought or oiling, in similar ways by losing pigment and water ultimately leading to plant mortality. Hence, any vegetation stress in the affected area cannot automatically be attributed to oil contamination. There are three potential ways to measure the effect of oiling on vegetation. First, a comparison of pre-spill imagery to post-spill imagery of the oil-spill region can determine loss of plant health due to oiling. However, as oil spills occur without warning, pre-spill imagery is not always available. Furthermore, a difference in plant health, if observed, might still be due to seasonal changes such as the arrival of the dry season. Second, an oil susceptibility analysis might help identify areas with higher probability of oiling and possibly even identify degree of vulnerability to oil impacts $[84,85]$. If the vegetation stress maps coincide with the susceptibility map predictions, it would potentially indicate oil effects. Third, if oil contamination can be mapped in the post-spill imagery, then vegetation in oiled areas can be compared to oil-free areas within the same region. Assuming that other sources of stress will affect the entire region, any differential in vegetation stress between oiled and oil-free areas could reasonably be attributed to oil contamination [20]. Mapping oil on land is harder than mapping it on water. Many studies have mapped oil spills on water with multispectral imagery [30,86,87], hyperspectral imagery [88,89], and RADAR [90-92]. But mapping oil on land requires spectroscopy data acquired at high spatial resolution [20]. Since the DWH oil spill was the largest oil spill in US history, the gulf shoreline was extensively mapped and surveyed with the help of airborne hyperspectral data to determine extent of oiling $[20,62,63,93]$. Hence this study uses the third approach to determine the impact of oil on wetland health.

\subsection{Spectral Resolution}

AVIRIS $_{W V 2}$ has the same spatial resolution as AVIRIS in this study $(3.5 \mathrm{~m})$ but broad-bands of 40-180 nm width instead of the $10 \mathrm{~nm}$ narrow-bands of the AVIRIS sensor. Thus, the effect spectral resolution is examined by comparing their performance. Several studies have shown that fine spectral resolution is important for species-level classification [22,94-96], in some cases, even more important than spatial resolution $[97,98]$. However, when the goal is to detect plant stress, especially when using indices, coarser spectral resolution may be sufficient, particularly when combined with fine spatial resolution [99,100]. Teillet et al. [99] calculated NDVI at various spatial and spectral resolutions and found that when bandwidth of the Red band increased beyond $50 \mathrm{~nm}$, there was an appreciable drop in the ability of the index to track plant health, and found similar results for other indices. As the Red band width for all three multispectral sensors we used is greater than $50 \mathrm{~nm}$, this is consistent with the above reported decrease in ability to track plant health (Red bandwidth, RapidEye: $55 \mathrm{~nm}$, WorldView2: $60 \mathrm{~nm}$, and Landsat ETM+: $60 \mathrm{~nm}$ ). Hence, it is expected that the loss of spectral resolution will degrade the ability to discriminate oil-induced plant stress. Our study demonstrated that there was loss of ability to detect vegetation stress with broader spectral bands, as AVIRIS was able to detect significant differences in vegetation index values up to $14 \mathrm{~m}$ inland (inland zones with lower oil impact) but AVIRIS ${ }_{W V 2}$ could not. Additionally, index value differences were weaker when using AVIRIS ${ }_{W V 2}$ in all zones.

Multiple studies have also pointed out the importance of a wider spectral range, specifically the advantage of having SWIR bands for detecting vegetation and vegetation stress [101-103]. Of the three multispectral sensors we tested, only Landsat ETM+ has SWIR bands, which we used to calculate NDII. 
The results of the Landsat NDII comparison showed that for AVIRIS $_{\text {LS-15m }}$, AVIRIS $_{\text {LS-30m }}$ and LS-15 $\mathrm{m}$ there was a stronger differentiation between oiled and oil-free shorelines using NDII than using ARed (no SWIR band). However, with the LS-30 m sensor data, ARed detected a significant response while NDII did not, indicating that this wider spectral range is not always necessary, which is likely due to an interaction with the effect of spatial resolution. However, such interactions between wider spectral range and spatial resolution need further investigation. Furthermore, a comparison of ARed and NDII using AVIRIS $3.5 \mathrm{~m}$ narrow-band data showed that ARed performed as well as NDII, again indicating that the presence of the SWIR band might not be critical to detection of vegetation stress. This could be because vegetation stress is identifiable across multiple regions of the electro-magnetic spectrum [37].

\subsection{Spatial Resolution}

The choice of the appropriate spatial resolution is important for the detection of oil-induced vegetation stress, and critical for the precise identification of the boundaries of the affected area. In this particular study, the impact was localized to a narrow $14 \mathrm{~m}$ band along the affected shoreline [20], and the degree of impact differed with distance from the shore. Hence it was important to have a spatial resolution finer than $14 \mathrm{~m}$ to delineate this oil impact. These impacts were easily detected at all resolutions except at Landsat $30 \mathrm{~m}$, but effect sizes declined rapidly as spatial resolution became coarser. At the Landsat $30 \mathrm{~m}$ pixel resolution, half of the area within the first pixel next to the shore is not affected by oil and the impacted vegetation is intermixed with healthy vegetation. This reduces the effect size, making it difficult to detect significant differences between stressed and non-stressed vegetation. However, to detect the gradient of stress inland from the shoreline, and to delineate the affected area with some degree of confidence, a finer spatial resolution is required as demonstrated by our results. Studies by Teillet et al. [99] and Paul et al. [104] suggested that required spatial resolution depends on the study goals and that coarse spatial resolution was sufficient for studies involving large targets. For example, Paul et al. [104] were trying to map the extent of debris-free glaciers wider than $100 \mathrm{~m}$ and found the Landsat TM resolution of $30 \mathrm{~m}$ to be sufficient. The results of our study corroborate this assertion that the aims of the study determine the resolution required. In this study, Landsat pan-sharpened $15 \mathrm{~m}$ imagery would have been sufficient to determine the length of shoreline affected by the oil spill, but would not be able to identify the depth of penetration or delineate the affected area. By using finer spatial resolution sensors like AVIRIS or WorldView2, we were able to examine depth and magnitude of oil impacts on vegetation. Our study site, Barataria Bay, has a consistent topography where a gradual increase in elevation at the shore creates distinct subtidal, intertidal and upland areas. The oil, coming in from offshore, penetrated to the high-tide mark thus confining the impact of the spill in a narrow $14 \mathrm{~m}$ band by the shoreline [20]. However, in other regions in the gulf, a different hydrology and topography forced a different outcome from the DWH oil spill [105]. For example, in low-lying Chandeleur Island mangroves, the tide penetrated much further spreading oil more uniformly and likely causing mortality due to coating of pneumatophores rather than the mangrove canopy and leaves [105]. Thus, in the mangrove ecosystem, coarser resolution imagery might have proved sufficient for identifying the impacted coastline as well as the area affected.

\subsection{Sensor Signal-to-Noise Ratio (SNR)}

While all multispectral sensors were successful in detecting significant vegetation stress along the oiled shores relative to oil-free shores, their performance was consistently inferior to AVIRIS. This remained true even when AVIRIS was spectrally and spatially resampled to match these other sensors. This suggests that factors other than spectral and spatial resolution also play a role in the performance.

The radiometric resolution of the four sensors tested in this study ranged from 8-bit quantization in Landsat images to 16-bit quantization for AVIRIS and RapidEye (Table 1). Since oil darkens the albedo in most bands from the visible to the SWIR, the radiometric range is unlikely to have a large impact on performance. Moreover, RapidEye performed no better than WorldView2 despite 
having higher radiometric resolution, suggesting that radiometric resolution did not affect performance. However, RapidEye has coarser spatial resolution compared to WorldView2 hence it is not possible to completely isolate the effect of radiometric resolution from the effect of spatial scale. Therefore, more specific tests might be needed to examine how radiometric resolution affects performance.

The signal-to-noise ratio of AVIRIS in both the visible and NIR regions is better than any of the other sensors [64-68]. Additionally, when AVIRIS was resampled to the multispectral sensors' characteristics, it likely performed better because each new band was calculated from the sum of several narrow bands with high SNR, increasing the signal strength of the resampled image [64]. Better SNR implies that the sensor is more likely to detect vegetation stress when present, and also more likely to discriminate small differences in vegetation stress. There are very few studies that compare the performance of different sensors based on their SNR. Platt and Goetz [64] compared AVIRIS performance to Landsat and concluded that the advantage of AVIRIS over Landsat when classifying land cover was due to spectral resolution, not SNR. However, the current study suggests that the AVIRIS signal is stronger compared to that of the other sensors, even when spectrally resampled.

Factors other than SNR may also have influenced the performance of the multispectral sensors. Both WorldView2 and RapidEye images were acquired off-nadir at oblique angles which can increase scattering across pixels, therefore making it more difficult to separate oiled from non-oiled areas. Additionally, multispectral sensors lack the narrow bands that allow accurate estimates of water vapor in the atmosphere and help achieve a better atmospheric calibration. Current (e.g., Landsat 8 , WorldView3, Sentinel-2) and future sensors may have SNR comparable to AVIRIS. A comparison with these sensors might yield different results. Landsat 8 was launched in 2013, WorldView3 in 2014, and Sentinel-2 in 2015, hence they were unavailable at the time of this oil spill in 2010, but could be useful for future disasters.

\subsection{Timing of Image Acquisition}

The WorldView2 imagery, while successful in detecting oil impacts, indicated a narrower shoreline zone affected by oil compared to the AVIRIS imagery. This is likely because the WorldView2 data were acquired at high tide. Tide levels were $29 \mathrm{~cm}$ higher at the time the WorldView2 images were acquired, compared to the AVIRIS image (NOAA, http://tidesandcurrents.noaa.gov/). This highlights the importance of tidal effects when the study area is dynamic and water levels are changing throughout the day. It is important to schedule image acquisitions (where possible e.g., in the case of airborne imagery) at low tide to expose maximum possible land area. In our study, this was especially important because the oil came inland from the shoreline resulting in the most affected area being next to the shore. The ability to control the timing of image acquisition is also important during the wet season or in high-rainfall regions like the tropics. The WorldView-2 imagery was also the one with the most cloud cover and parts of the oiled shoreline were under clouds and could not be analyzed at all. The difference in timing between the AVIRIS and RapidEye imagery also likely explains the poor performance of Rapid Eye, which was collected almost a month later than the data from the other sensors. With satellite imagery, there is very little control over the time of acquisition which can result in underestimation of the affected area and its impacts on vegetation stress.

\section{Conclusions}

Multispectral sensor imagery is relatively more economical than hyperspectral imagery and is now often available at a fine spatial resolution making it an excellent tool for mapping impact and monitoring recovery of ecosystems after environmental disasters such as oil spills, floods, and hurricanes. This study examined the potential of three multispectral sensors with considerably less financial costs than AVIRIS (i.e., WorldView2 is estimated at half the cost of AVIRIS, RapidEye at a fraction of the cost, and Landsat ETM+ is free) for mapping the extent of the impact of the $2010 \mathrm{DWH}$ oil spill on the wetlands of Louisiana. If accuracy is prioritized, clearly AVIRIS data performed the best, even when resampled to coarser spectral and spatial resolutions. This indicates that sensor 
characteristics, such as signal-to-noise ratio, are critical in detecting vegetation stress. WorldView2 and RapidEye were unable to detect oil impact to the same inland distance as AVIRIS. In the case of WorldView 2 this might be because of high tides covering oiled areas denuded of vegetation, and in the case of RapidEye the late acquisition date. Landsat ETM+ $15 \mathrm{~m}$ data gave mixed results likely due to its coarse spatial resolution.

Spatial resolution was therefore the most critical factor limiting the detection of the extent of oil impact although spectral resolution and sensor characteristics (e.g., SNR, sensor view angle, etc.) also limited the ability to detect vegetation stress. Based on these results we suggest that since no sensor has all of the characteristics necessary to detect extent, impact, and recovery from oil spills, it is important to determine which sensor is best for the objectives of a particular project. If the objective is to map the extent of oil impact, sensors like WorldView2 and RapidEye, or even Landsat, are sufficient if the impact is widespread. If the objective is to detect vegetation stress and recovery, and delineate the affected area for treatment, then it is important to have high spectral and spatial resolution collected at the optimal time to reveal the stress, as these characteristics allow for detecting even subtle differences in vegetation condition. The results of this study provide important guidelines for sensor selection which requires careful consideration of the extent of impact, location of the affected area, degree of complexity required in detection of impact, and characteristics of the study area which might require specific timing of image acquisition. In mapping the impact of an event such as an oil spill, additional fine resolution imagery might be required to map the extent of oil after the spill since multispectral imagers don't have the necessary bands to detect oil presence on soil or vegetation.

Acknowledgments: This work has been partially funded by a NASA Terrestrial Ecology grant (\#NNX12AK58G). We thank Diane Wickland, program manager for Terrestrial Ecology at NASA, for providing access to the AVIRIS database and to the AVIRIS team for preprocessing support. We thank George Scheer for systems support, and Keely Roth for discussions and guidance in statistical methods.

Author Contributions: S.K. wrote the manuscript, conducted most of the analysis, and interpreted results. M.J.S. provided critical advice on analysis methods and interpretation of results and helped with every section of the written manuscript. S.L.U. provided lab resources, advice on methods and interpretation, and edited the manuscript. K.S., P.J.H. and M.L. helped in preparing and preprocessing image data, extracting data for analysis and editing the manuscript.

Conflicts of Interest: The authors declare no conflict of interest.

\section{References}

1. Reimold, R.J.; Hardisky, M.A. Nonconsumptive use of values of wetlands. In Wetland Functions and Values; Greeson, P.E., Clark, J.R., Clark, J.E., Eds.; American Water Resources Association: Minneapolis, MN, USA, 1979; pp. 558-564.

2. Barbier, E.B.; Hacker, S.D.; Kennedy, C.; Koch, E.W.; Stier, A.C.; Silliman, B.R. The value of estuarine and coastal ecosystem services. Ecol. Monogr. 2011, 81, 169-193. [CrossRef]

3. Barbier, E.B.; Koch, E.W.; Silliman, B.R.; Hacker, S.D.; Wolanski, E.; Primavera, J.; Granek, E.F.; Polasky, S.; Aswani, S.; Cramer, L.A.; et al. Coastal Ecosystem-Based Management with Nonlinear Ecological Functions and Values. Science 2008, 319, 321-323. [CrossRef] [PubMed]

4. Kirwan, M.L.; Megonigal, J.P. Tidal wetland stability in the face of human impacts and sea-level rise. Nature 2013, 504, 53-60. [CrossRef] [PubMed]

5. Liquete, C.; Piroddi, C.; Drakou, E.G.; Gurney, L.; Katsanevakis, S.; Charef, A.; Egoh, B. Current Status and Future Prospects for the Assessment of Marine and Coastal Ecosystem Services: A Systematic Review. PLoS ONE 2013, 8, e67737. [CrossRef] [PubMed]

6. Temmerman, S.; Meire, P.; Bouma, T.J.; Herman, P.M.J.; Ysebaert, T.; De Vriend, H.J. Ecosystem-based coastal defence in the face of global change. Nature 2013, 504, 79-83. [CrossRef] [PubMed]

7. Duarte, C.M.; Losada, I.J.; Hendriks, I.E.; Mazarrasa, I.; Marba, N. The role of coastal plant communities for climate change mitigation and adaptation. Nature Clim. Chang. 2013, 3, 961-968. [CrossRef] 
8. Möller, I.; Kudella, M.; Rupprecht, F.; Spencer, T.; Paul, M.; van Wesenbeeck, B.K.; Wolters, G.; Jensen, K.; Bouma, T.J.; Miranda-Lange, M.; et al. Wave attenuation over coastal salt marshes under storm surge conditions. Nat. Geosci. 2014, 7, 727-731. [CrossRef]

9. Blum, M.D.; Roberts, H.H. Drowning of the Mississippi Delta due to insufficient sediment supply and global sea-level rise. Nat. Geosci. 2009, 2, 488-491. [CrossRef]

10. Blum, M.D.; Roberts, H.H. The Mississippi Delta Region: Past, Present, and Future. AREPS 2012, 40, $655-683$. [CrossRef]

11. Day, J.; Britsch, L.; Hawes, S.; Shaffer, G.; Reed, D.; Cahoon, D. Pattern and process of land loss in the Mississippi Delta: A Spatial and temporal analysis of wetland habitat change. Estuaries 2000, 23, 425-438. [CrossRef]

12. Conner, W.; Day, J., Jr.; Baumann, R.; Randall, J. Influence of hurricanes on coastal ecosystems along the northern Gulf of Mexico. Wetlands Ecol. Manag. 1989, 1, 45-56. [CrossRef]

13. Gundlach, E.R.; Hayes, M.O. Vulnerability of coastal environments to oil spill impacts. Mar. Technol. Soc. J. 1978, 12, 18-27.

14. Burk, J.C. A Four Year Analysis of Vegetation Following an Oil Spill in a Freshwater Marsh. J. Appl. Ecol. 1977, 14, 515-522. [CrossRef]

15. Hester, M.W.; Mendelssohn, I.A. Long-term recovery of a Louisiana brackish marsh plant community from oil-spill impact: Vegetation response and mitigating effects of marsh surface elevation. Mar. Environ. Res. 2000, 49, 233-254. [CrossRef]

16. Lin, Q.; Mendelssohn, I.A. Impacts and recovery of the Deepwater Horizon Oil Spill on vegetation structure and function of coastal salt marshes in the northern gulf of Mexico. Environ. Sci. Technol. 2012, 46, 3737-3743. [CrossRef] [PubMed]

17. Ramseur, J.L. Oil Spills in U.S. Coastal Waters: Background, Governance, and Issues for Congress; Congressional Research Service: Washington, DC, USA, 2010.

18. Moss, L. The 13 largest oil spills in history. In Mother Nature Network; Narrative Content Group: Atlanta, GA, USA, 2010.

19. Judy, C.R.; Graham, S.A.; Lin, Q.; Hou, A.; Mendelssohn, I.A. Impacts of Macondo oil from Deepwater Horizon spill on the growth response of the common reed Phragmites australis: A mesocosm study. Mar. Pollut. Bull. 2014, 79, 69-76. [CrossRef] [PubMed]

20. Khanna, S.; Santos, M.J.; Ustin, D.S.L.; Koltunov, A.; Kokaly, R.F.; Roberts, D.A. Detection of salt marsh vegetation stress after the Deepwater Horizon BP oil spill along the shoreline of gulf of Mexico using AVIRIS data. PLoS ONE 2013, 8, e78989. [CrossRef] [PubMed]

21. Lin, Q.; Mendelssohn, I.A.; Graham, S.A.; Hou, A.; Fleeger, J.W.; Deis, D.R. Response of salt marshes to oiling from the Deepwater Horizon spill: Implications for plant growth, soil surface-erosion, and shoreline stability. Sci. Total Environ. 2016, 557-558, 369-377. [CrossRef] [PubMed]

22. Mishra, D.R.; Cho, H.J.; Ghosh, S.; Fox, A.; Downs, C.; Merani, P.B.T.; Kirui, P.; Jackson, N.; Mishra, S. Post-spill state of the marsh: Remote estimation of the ecological impact of the Gulf of Mexico oil spill on Louisiana Salt Marshes. Remote Sens. Environ. 2012, 118, 176-185. [CrossRef]

23. Silliman, B.R.; van de Koppel, J.; McCoy, M.W.; Diller, J.; Kasozi, G.N.; Earl, K.; Adams, P.N.; Zimmerman, A.R. Degradation and resilience in Louisiana salt marshes after the BP-Deepwater Horizon oil spill. Proc. Natl. Acad. Sic. USA 2012, 109, 11234-11239. [CrossRef] [PubMed]

24. Wiens, J.A. Review of an ecosystem services approach to assessing the impacts of the Deepwater Horizon Oil Spill in the Gulf of Mexico. Fisheries 2015, 40, 86. [CrossRef]

25. Ko, J.Y.; Day, J.W. A review of ecological impacts of oil and gas development on coastal ecosystems in the Mississippi Delta. Ocean Coast. Manag. 2004, 47, 597-623. [CrossRef]

26. Pezeshki, S.R.; Hester, M.W.; Lin, Q.; Nyman, J.A. The effects of oil spill and clean-up on dominant US Gulf coast marsh macrophytes: A review. Environ. Pollut. 2000, 108, 129-139. [CrossRef]

27. Smith, C.J.; Delaune, R.D.; Patrick, W.H.; Fleeger, J.W. Impact of dispersed and undispersed oil entering a gulf coast salt marsh. Environ. Toxicol. Chem. 1984, 3, 609-616. [CrossRef]

28. Pezeshki, S.R.; DeLaune, R.D. United States Gulf of Mexico Coastal Marsh Vegetation Responses and Sensitivities to Oil Spill: A Review. Environments 2015, 2, 586-607. [CrossRef]

29. Lin, Q.; Mendelssohn, I.A. A comparative investigation of the effects of south Louisiana crude oil on the vegetation of fresh, brackish and salt marshes. Mar. Pollut. Bull. 1996, 32, 202-209. [CrossRef] 
30. Kenworthy, W.J.; Durako, M.J.; Fatemy, S.M.R.; Valavi, H.; Thayer, G.W. Ecology of seagrasses in northeastern Saudi Arabia one year after the Gulf War oil spill. Mar. Pollut. Bull. 1993, 27, 213-222. [CrossRef]

31. Khanna, S.; Santos, M.; Koltunov, A.; Shapiro, K.; Lay, M.; Ustin, S. Marsh Loss Due to Cumulative Impacts of Hurricane Isaac and the Deepwater Horizon Oil Spill in Louisiana. Remote Sens. 2017, 9, 169. [CrossRef]

32. Jackson, J.B.C.; Cubit, J.D.; Keller, B.D.; Batista, V.; Burns, K.; Caffey, H.M.; Caldwell, R.L.; Garrity, S.D.; Getter, C.D.; Gonzalez, C.; et al. Ecological effects of a major oil spill on Panamanian coastal marine communities. Science 1989, 243, 37-44. [CrossRef] [PubMed]

33. Walker, D.A.; Webber, P.J.; Everett, K.R.; Brown, J. Effects of Crude and Diesel Oil Spills on Plant Communities at Prudhoe Bay, Alaska, and the Derivation of Oil Spill Sensitivity Maps. Arctic 1978, 31, 242-259. [CrossRef]

34. Houborg, R.; Soegaard, H.; Boegh, E. Combining vegetation index and model inversion methods for the extraction of key vegetation biophysical parameters using Terra and Aqua MODIS reflectance data. Remote Sens. Environ. 2007, 106, 39-58. [CrossRef]

35. Jurgens, C. The modified normalized difference vegetation index (mNDVI) a new index to determine frost damages in agriculture based on Landsat TM data. Int. J. Remote Sens. 1997, 18, 3583-3594. [CrossRef]

36. Peñuelas, J.; Gamon, J.A.; Griffin, K.L.; Field, C.B. Assessing community type, plant biomass, pigment composition, and photosynthetic efficiency of aquatic vegetation from spectral reflectance. Remote Sens. Environ. 1993, 46, 110-118. [CrossRef]

37. Ustin, S.L.; Gitelson, A.A.; Jacquemoud, S.; Schaepman, M.; Asner, G.P.; Gamon, J.A.; Zarco-Tejada, P. Retrieval of foliar information about plant pigment systems from high resolution spectroscopy. Remote Sens. Environ. 2009, 113, S67-S77. [CrossRef]

38. Zarco-Tejada, P.J.; Rueda, C.A.; Ustin, S.L. Water content estimation in vegetation with MODIS reflectance data and model inversion methods. Remote Sens. Environ. 2003, 85, 109-124. [CrossRef]

39. Gitelson, A.; Merzlyak, M.N. Spectral reflectance changes associated with autumn senescence of Aesculus-hippocastanum L. and Acer-platanoides L. leaves-Spectral features and relation to chlorophyll estimation. J. Plant Physiol. 1994, 143, 286-292. [CrossRef]

40. Gitelson, A.A.; Merzlyak, M.N. Remote estimation of chlorophyll content in higher plant leaves. Int. J. Remote Sens. 1997, 18, 2691-2697. [CrossRef]

41. Fensholt, R.; Sandholt, I. Derivation of a shortwave infrared water stress index from MODIS near- and shortwave infrared data in a semiarid environment. Remote Sens. Environ. 2003, 87, 111-121. [CrossRef]

42. Gao, B.C. NDWI-Normalized difference water index for remote sensing of vegetation liquid water from space. Remote Sens. Environ. 1996, 58, 257-266. [CrossRef]

43. Hunt, E.R.; Rock, B.N. Detection of changes in leaf water content using near-infrared and middle-infrared reflectances. Remote Sens. Environ. 1989, 30, 43-54.

44. Khanna, S.; Palacios-Orueta, A.; Whiting, M.L.; Ustin, S.L.; Riano, D.; Litago, J. Development of angle indexes for soil moisture estimation, dry matter detection and land-cover discrimination. Remote Sens. Environ. 2007, 109, 154-165. [CrossRef]

45. Lillesand, T.M.; Kiefer, R.W.; Chipman, J.W. Remote Sensing and Image Interpretation; John Wiley \& Sons, Inc.: New York, NY, USA, 2004.

46. Richardson, A.J.; Wiegand, C.L. Distinguishing Vegetation from Soil Background Information. Photogramm. Eng. Remote Sens. 1977, 43, 1541-1552.

47. Tucker, C.J. Red and photographic infrared linear combinations for monitoring vegetation. Remote Sens. Environ. 1979, 8, 127-150. [CrossRef]

48. Palacios-Orueta, A.; Whiting, M.L.; Ustin, S.L.; Litago, J.; Garcia, M.; Khanna, S. Cotton phenology analysis with the new remote sensing spectral angle indexes AS1 and AS2. In Proceedings of the International Conference on Agricultural Engineering, Crete, Greece, 23-25 June 2008.

49. Li, L.; Ustin, S.L.; Lay, M. Application of AVIRIS data in detection of oil-induced vegetation stress and cover change at Jornada, New Mexico. Remote Sens. Environ. 2005, 94, 1-16. [CrossRef]

50. Boochs, F.; Kupfer, G.; Dockter, K.; Kühbauch, W. Shape of the red edge as vitality indicator for plants. Int. J. Remote Sens. 1990, 11, 1741-1753. [CrossRef]

51. Carter, G.A. Responses of Leaf Spectral Reflectance to Plant Stress. Am. J. Bot. 1993, 80, 239-243. [CrossRef]

52. Bammel, B.H.; Birnie, R.W. Spectral Reflectance Response of Big Sagebrush to Hydrocarbon-Induced Stress in the Bighorn Basin, Wyoming; American Society for Photogrammetry and Remote Sensing: Bethesda, MD, USA, 1994; Volume 60. 
53. Rosso, P.H.; Pushnik, J.C.; Lay, M.; Ustin, S.L. Reflectance properties and physiological responses of Salicornia virginica to heavy metal and petroleum contamination. Environ. Pollut. 2005, 137, 241-252. [CrossRef] [PubMed]

54. Van Der Meer, F.; Van Dijk, P.; Van Der Werff, H.; Yang, H. Remote sensing and petroleum seepage: A review and case study. Terra Nova 2002, 14, 1-17. [CrossRef]

55. Yang, H.; Zhang, J.; Van der Meer, F.; Kroonenberg, S.B. Geochemistry and field spectrometry for detecting hydrocarbon microseepage. Terra Nova 1998, 10, 231-235. [CrossRef]

56. Wilson, C.A.; Allison, M.A. An equilibrium profile model for retreating marsh shorelines in southeast Louisiana. Estuar. Coast. Shelf Sci. 2008, 80, 483-494. [CrossRef]

57. Gosselink, J.G.; Pendleton, E.C. The Ecology of Delta Marshes of Coastal Louisiana: A Community Profile; U.S. Fish and Wildlife Service: Washington DC, USA, 1984; p. 156.

58. Jones, C.E.; Minchew, B.; Holt, B.; Hensley, S. Studies of the Deepwater Horizon Oil Spill With the UAVSAR Radar. In Monitoring and Modeling the Deepwater Horizon Oil Spill: A Record-Breaking Enterprise; AGU: Washington, DC, USA, 2011; Volume 195, pp. 33-50.

59. Liu, P.; Li, X.; Qu, J.J.; Wang, W.; Zhao, C.; Pichel, W. Oil spill detection with fully polarimetric UAVSAR data. Mar. Pollut. Bull. 2011, 62, 2611-2618. [CrossRef] [PubMed]

60. Michel, J.; Owens, E.H.; Zengel, S.; Graham, A.; Nixon, Z.; Allard, T.; Holton, W.; Reimer, P.D.; Lamarche, A.; White, M.; et al. Extent and degree of shoreline oiling: Deepwater Horizon oil spill, Gulf of Mexico, USA. PLoS ONE 2013, 8, e65087. [CrossRef] [PubMed]

61. Ramsey, E., III; Rangoonwala, A.; Suzuoki, Y.; Jones, C.E. Oil detection in a coastal marsh with polarimetric Synthetic Aperture Radar (SAR). Remote Sens. 2011, 3, 2630-2662. [CrossRef]

62. Kokaly, R.F.; Couvillion, B.R.; Holloway, J.M.; Roberts, D.A.; Ustin, S.L.; Peterson, S.H.; Khanna, S.; Piazza, S.C. Spectroscopic remote sensing of the distribution and persistence of oil from the Deepwater Horizon spill in Barataria Bay marshes. Remote Sens. Environ. 2013, 129, 210-230. [CrossRef]

63. Kokaly, R.F.; Heckman, D.; Holloway, J.; Piazza, S.C.; Couvillion, B.R.; Steyer, G.D.; Mills, C.T.; Hoefen, T.M. Shoreline surveys of Oil-Impacted Marsh in Southern Louisiana, July to August 2010; U.S. Geological Survey: Reston, VA, USA, 2011.

64. Platt, R.V.; Goetz, A.F.H. A Comparison of AVIRIS and Landsat for Land Use Classification at the Urban Fringe. Photogram. Eng. Remote Sens. 2004, 70, 813-819. [CrossRef]

65. Miecznik, G.; Grabowska, D. Worldview-2 bathymetric capabilities. In Proceedings of the Algorithms and Technologies for Multispectral, Hyperspectral, and Ultraspectral Imagery XVIII, Baltimore, MD, USA, 23-27 April 2012; pp. 83901J-1-83901J-10.

66. Brunn, A.; Freedman, E.; Fleming, R. New Resampling Kernel and Its Effect on RapidEye Imagery. Available online: http:/ / www.serioussciencellc.com/files/CMTF_JACIE2013.pdf (accessed on 9 February 2014).

67. Reulke, R.; Weichelt, H. SNR Evaluation of the RapidEye Space-borne Cameras. Photogramm.-Fernerkund.-Geoinf. 2012, 2012, 29-38. [CrossRef]

68. Mika, A.M. Three Decades of Landsat Instruments. Photogramm. Eng. Remote Sens. 1997, 63, 839-852.

69. Richter, R.; Schläpfer, D. Geo-atmospheric processing of airborne imaging spectrometry data. Part 2: Atmospheric/topographic correction. Int. J. Remote Sens. 2002, 23, 2631-2649. [CrossRef]

70. Ben-Dor, E.; Kindel, B.C.; Patkin, K. A comparison between six model-based methods to retrieve surface reflectance and water vapor content from hyperspectral data: A case study using synthetic AVIRIS data. In Proceedings of the International Conference on Optics and Optoelectronics, Dehradun, India, 12-15 December 2005.

71. Koltunov, A.; Ben-Dor, E.; Ustin, S.L. Image construction using multitemporal observations and Dynamic Detection Models. Int. J. Remote Sens. 2008, 30, 57-83. [CrossRef]

72. Koltunov, A.; Ustin, S.L.; Quayle, B.; Schwind, B. GOES Early Fire Detection (GOES-EFD) system prototype. In Proceedings of the ASPRS 2012 Anuual Conference, Sacramento, CA, USA, 19-23 March 2012.

73. Khanna, S.; Santos, M.J.; Ustin, S.L.; Haverkamp, P.J. An integrated approach to a biophysiologically based classification of floating aquatic macrophytes. Int. J. Remote Sens. 2011, 32, 1067-1094. [CrossRef]

74. Clark, R.N.; Roush, T.L. Reflectance spectroscopy-Quantitative analysis techniques for remote sensing applications. J. Geophys. Res. Solid Earth 1984, 89, 6329-6340. [CrossRef]

75. Rosenfield, G.H.; Fitzpatrick-Lins, K. A coefficient of agreement as a measure of thematic classification accuracy. Photogramm. Eng. Remote Sens. 1986, 52, 223-227. 
76. Story, M.; Congalton, R.G. Accuracy assessment-A user's perspective (map interpretation). Photogramm. Eng. Remote Sens. 1986, 52, 397-399.

77. Laben, C.A.; Brower, B.V. Process for Enhancing the Spatial Resolution of Multispectral Imagery Using Pan-Sharpening. U.S. Patent 6,011,875, 4 January 2000.

78. Mitsch, W.J.; Gosselink, J.G. Wetlands; John Wiley \& Sons, Inc.: New York, NY, USA, 2007.

79. Hardisky, M.A.; Klemas, V.; Smart, R.M. The influence of soil-salinity, growth form, and leaf moisture on the spectral radiance of Spartina-alterniflora canopies. Photogramm. Eng. Remote Sens. 1983, 49, 77-83.

80. Palacios-Orueta, A.; Khanna, S.; Litago, J.; Whiting, M.L.; Ustin, S.L. Assessment of NDVI and NDWI spectral indices using MODIS time series analysis and development of a new spectral index based on MODIS shortwave infrared bands. In Proceedings of the 1st international conference of remote sensing and geoinformation processing, Trier, Germany, 7-9 September 2005; pp. 207-209.

81. Cohen, J. Statistical Power Analysis for the Behavioral Sciences; Academic Press: New York, NY, USA, 1969.

82. Cohen, J. Statistical Power Analysis for the Behavioral Sciences, 2nd ed.; Lawrence Earlbaum Associates: Hillsdale, NJ, USA, 1988.

83. Khanna, S.; Santos, M.J.; Hestir, E.L.; Ustin, S.L. Plant community dynamics relative to the changing distribution of a highly invasive species, Eichhornia crassipes: A remote sensing perspective. Biol. Invasions 2012, 14, 717-733. [CrossRef]

84. Alves, T.M.; Kokinou, E.; Zodiatis, G. A three-step model to assess shoreline and offshore susceptibility to oil spills: The South Aegean (Crete) as an analogue for confined marine basins. Mar. Pollut. Bull. 2014, 86, 443-457. [CrossRef] [PubMed]

85. Alves, T.M.; Kokinou, E.; Zodiatis, G.; Lardner, R.; Panagiotakis, C.; Radhakrishnan, H. Modelling of oil spills in confined maritime basins: The case for early response in the Eastern Mediterranean Sea. Environ. Pollut. 2015, 206, 390-399. [CrossRef] [PubMed]

86. Al-Awadhi, J.M.; Omar, S.A.; Misak, R.F. Land degradation indicators in Kuwait. LDD 2005, 16, $163-176$. [CrossRef]

87. Cross, A.M. Monitoring marine oil pollution using AVHRR data : Observation of the coast of Kuwait and Saudi Arabia during January 1991. Int. J. Remote Sens. 1992, 13, 781-788. [CrossRef]

88. Bianchi, R.; Cavalli, R.M.; Marino, C.M.; Pignatti, S.; Poscolieri, M. Use of airborne hyperspectral images to assess the spatial distribution of oil spilled during the Trecate blow-out (Northern Italy). In Proceedings of the Remote Sensing for Agriculture, Forestry, and Natural Resources, Paris, France, 26-28 September 1995; pp. 352-362.

89. Salem, F.; Kafatos, M. Hyperspectral Image Analysis for Oil Spill Mitigation. In Proceedings of the 22nd Asian Conference on Remote Sensing, Singapore, 5-9 November 2001.

90. Brekke, C.; Solberg, A.H.S. Oil spill detection by satellite remote sensing. Remote Sens. Environ. 2005, 95, 1-13. [CrossRef]

91. DiGiacomo, P.M.; Washburn, L.; Holt, B.; Jones, B.H. Coastal pollution hazards in southern California observed by SAR imagery: Stormwater plumes, wastewater plumes, and natural hydrocarbon seeps. Mar. Pollut. Bull. 2004, 49, 1013-1024. [CrossRef] [PubMed]

92. Simecek-Beatty, D.; Clemente-Colón, P. Locating a sunken vessel using SAR imagery: Detection of oil spilled from the SS Jacob Luckenbach. Int. J. Remote Sens. 2004, 25, 2233-2241. [CrossRef]

93. Peterson, S.H.; Roberts, D.A.; Beland, M.; Kokaly, R.F.; Ustin, S.L. Oil detection in the coastal marshes of Louisiana using MESMA applied to band subsets of AVIRIS data. Remote Sens. Environ. 2015, 159, 222-231. [CrossRef]

94. Cho, H.; Lee, K.-S. Comparison between Hyperspectral and Multispectral Images for the Classification of Coniferous Species. Korean J. Remote Sens. 2014, 30, 25-36. [CrossRef]

95. Govender, M.; Chetty, K.; Naiken, V.; Bulcock, H. A comparison of satellite hyperspectral and multispectral remote sensing imagery for improved classification and mapping of vegetation. Water SA 2008, 34, 147-154.

96. Santos, M.J.; Hestir, E.L.; Khanna, S.; Ustin, S.L. Image spectroscopy and stable isotopes elucidate functional dissimilarity between native and nonnative plant species in the aquatic environment. New Phytol. 2012, 193, 683-695. [CrossRef] [PubMed]

97. Mumby, P.J.; Edwards, A.J. Mapping marine environments with IKONOS imagery: Enhanced spatial resolution can deliver greater thematic accuracy. Remote Sens. Environ. 2002, 82, 248-257. [CrossRef] 
98. Underwood, E.; Ustin, S.; Ramirez, C. A Comparison of Spatial and Spectral Image Resolution for Mapping Invasive Plants in Coastal California. Environ. Manage. 2007, 39, 63-83. [CrossRef] [PubMed]

99. Teillet, P.M.; Staenz, K.; William, D.J. Effects of spectral, spatial, and radiometric characteristics on remote sensing vegetation indices of forested regions. Remote Sens. Environ. 1997, 61, 139-149. [CrossRef]

100. Van Wagtendonk, J.W.; Root, R.R.; Key, C.H. Comparison of AVIRIS and Landsat ETM+ detection capabilities for burn severity. Remote Sens. Environ. 2004, 92, 397-408. [CrossRef]

101. Asner, G.P.; Heidebrecht, K.B. Spectral unmixing of vegetation, soil and dry carbon cover in arid regions: Comparing multispectral and hyperspectral observations. Int. J. Remote Sens. 2002, 23, 3939-3958. [CrossRef]

102. Bach, H.; Mauser, W. Improvements of plant parameter estimations with hyperspectral data compared to multispectral data. In Proceedings of the Remote Sensing of Vegetation and Sea, Taormina, Italy, 23-26 September 1996; pp. 59-67.

103. Lee, K.-S.; Cohen, W.B.; Kennedy, R.E.; Maiersperger, T.K.; Gower, S.T. Hyperspectral versus multispectral data for estimating leaf area index in four different biomes. Remote Sens. Environ. 2004, 91, 508-520. [CrossRef]

104. Paul, F.; Huggel, C.; Kääb, A.; Kellenberger, T.; Maisch, M. Comparison of TM-Derived Glacier Areas with Higher Resolution Data Sets. In Proceedings of the EARSeL-LISSIG-Workshop Observing our Cryosphere from Space, Bern, Switzerland, 11-13 March 2002.

105. Shapiro, K.; Khanna, S.; Ustin, S.L. Differential Impact and Recovery of Oil-induced Stress on Three Diverse Sites in the Gulf of Mexico due to the BP Deepwater Horizon Oil Spill. In Proceedings of the Ecological Society of America, Sacramento, CA, USA, 10-14 August 2014.

(C) 2018 by the authors. Licensee MDPI, Basel, Switzerland. This article is an open access article distributed under the terms and conditions of the Creative Commons Attribution (CC BY) license (http:/ / creativecommons.org/licenses/by/4.0/). 